Discussion Paper No. 10-050

A Macroeconomic Model for the Evaluation of Labor Market Reforms

Tom Krebs and Martin Scheffel

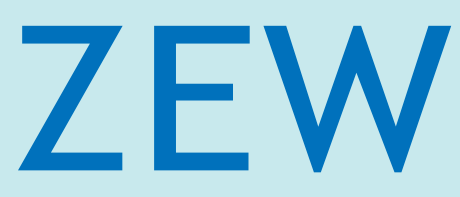

Zentrum für Europäische Wirtschaftsforschung $\mathrm{GmbH}$

Centre for European

Economic Research 
Discussion Paper No. 10-050

\section{A Macroeconomic Model for the Evaluation of Labor Market Reforms}

Tom Krebs and Martin Scheffel

Download this ZEW Discussion Paper from our ftp server:

ftp://ftp.zew.de/pub/zew-docs/dp/dp10050.pdf

Die Discussion Papers dienen einer möglichst schnellen Verbreitung von neueren Forschungsarbeiten des ZEW. Die Beiträge liegen in alleiniger Verantwortung der Autoren und stellen nicht notwendigerweise die Meinung des ZEW dar.

Discussion Papers are intended to make results of ZEW research promptly available to other economists in order to encourage discussion and suggestions for revisions. The authors are solely responsible for the contents which do not necessarily represent the opinion of the ZEW. 


\section{Non-Technical Summary}

The empirical literature documents a substantial and rising amount of labor income risk, in particular, employment risk. In most countries, the government provides insurance against this type of risk through the payment of unemployment benefits. Other things being equal, the provision of unemployment insurance increases the welfare of risk-averse households. However, unemployment benefits also discourage unemployed households from exerting search effort thereby raising the overall unemployment rate. When employment drops, so does aggregate output. In designing the unemployment insurance system, governments therefore have to weigh the insurance benefits against the costs of distorted incentives.

The latest major labor market reforms in Germany (Hartz Reforms) became effective in 2005 and 2006. The 2005-reform reduced the benefit payments for long-term unemployed households while the 2006-reform shortened the eligibility period for high benefit payments. Both reforms aimed at putting more weight on the incentive side of the unemployment benefit system. While the effect on the employment rate and production is unambiguously positive, it is due to the loss of insurance a priori not clear, how the new system is valued by the people. The valuation of these reforms, the so called welfare effect, is the ultimate performance measure of labor market reforms from the perspective of the society and can only be computed on the theory-based macroeconomic model.

The purpose of this paper is to develop a tractable macroeconomic model, and to use a calibrated version of the model to evaluate the quantitative effects of the Hartz Reforms on unemployment, growth, and welfare. We find that first, the 2005-reform had ceteris paribus large employment effects: the equilibrium unemployment rate has been reduced by approximately 1.1 percentage points from 7.5 to 6.4 percent. Second, the drop in unemployment has led to substantial output gains. Third, employed and short-term unemployed households experienced a significant welfare gain, that is, the positive incentive effect dominates the negative insurance effect. However, the long-term unemployed have lost in welfare terms. Fourth, the effects of the 2006-reform are qualitatively similar, but quantitatively much smaller. Finally, a further decrease in the benefit rate leads only to small additional welfare gains. 


\section{Das Wichtigste in Kürze}

Die empirische Literatur dokumentiert ein beachtliches Maß an Arbeitseinkommensrisiken, insbesondere verursacht durch das Risiko arbeitslos zu werden. Die meisten Länder stellen eine Versicherung gegen diese Einkommensrisiken in Form von Arbeitslosenunterstützung zur Verfügung was, ceteris paribus, die Wohlfahrt risiko-averser Haushalte erhöht. Die Zahlung von Arbeitslosengeld entmutigt jedoch arbeitslose Haushalte, Suchanstrengungen zu unternehmen, sodass die Arbeitslosenquote steigt und die Produktionsleistung abnimmt. Bei der Wahl des Arbeitslosenversicherungssystems müssen die Regierungen daher die Wohlfahrtsgewinne einer Versicherung gegen die Wohlfahrtsverluste einer falschen Anreizsetzung abwägen.

Die jüngsten großen Arbeitsmarktreformen in Deutschland (Hartz Reformen) traten 2005 und 2006 in Kraft. Mit der Reform von 2005 wurden die Zahlungen an Langzeitarbeitslose drastisch reduziert, wohingegen die Reform aus dem Jahr 2006 die Bezugsdauer von Arbeitslosengeld I verkürzte. Beide Reformen zielten darauf ab, verstärkt Suchanreize zu schaffen. Während die Auswirkungen dieser Reformen auf die Beschäftigung und Produktionsleistung zweifellos positiv sind, ist es aufgrund des verlorenen Versicherungsschutzes a priori nicht klar, wie das neue Versicherungssystem von den Haushalten bewertet wird. Die Bewertung dieser Reformen, die sogenannten Wohlfahrtseffekte, ist das geeignete Erfolgsmaß aus Sicht der Gesellschaft und kann nur auf Basis eines theoretischen makroökonomischen Modells ermittelt werden.

Ziel dieses Papiers ist es, ein makroökonomisches Modell zu entwickeln, es zu kalibrieren und die quantitativen Effekte der Hartz Reformen auf Arbeitslosigkeit, Wachstum, und Wohlfahrt zu evaluieren. Unsere Ergebnisse sind wie folgt: Erstens, die Reform von 2005 hat, ceteris paribus, große Beschäftigungseffekte. Die Arbeitslosenquote sinkt um etwa 1,1 Prozentpunkte von 7,5 v.H. auf 6,4 v.H. Dies führt zweitens zu einem beachtlichen Anstieg der Produktionsleistung. Drittens, sowohl Beschäftigte als auch Kurzzeitarbeitslose profitieren von den Reformen und realisieren signifikante Wohlfahrtsgewinne. Demzufolge dominiert für diese Gruppe der positive Anreizeffekt den Verlust an Versicherung. Viertens, die Effekte der Reform von 2006 sind qualitativ vergleichbar, quantitativ jedoch substanziell geringer. Abschließend führt eine weitere Reduktion des Arbeitslosengelds II lediglich zu geringen zusätzlichen Wohlfahrtsgewinnen. 


\title{
A Macroeconomic Model for the Evaluation of Labor Market
}

\author{
Reforms*
}

\author{
Tom Krebs $^{\dagger} \quad$ Martin Scheffel ${ }^{\ddagger}$
}

August 2010

\begin{abstract}
We develop a tractable macroeconomic model with employment risk and labor market search in order evaluate the effects of labor market reform on unemployment, growth, and welfare. The model has a large number of risk-averse households who can invest in risk-free physical capital and risky human capital. Unemployed households receive unemployment benefits and decide how much search effort to exert. We present a theoretical characterization result that facilitates the computation of equilibria substantially. We calibrate the model to German data and use the calibrated model economy to simulate the macroeconomic effects of the German labor market reforms of 2005 and 2006 (Hartz Reforms). We find that the 2005reform had large employment effects: the equilibrium unemployment rate has been reduced by approximately 1.1 percentage points from 7.5 to 6.4 percent. Moreover, the drop in unemployment has led to substantial output gains. Finally, employed and short-term unemployed households experienced significant welfare gains, whereas the long-term unemployed have lost in welfare terms. The effects of the 2006-reform are qualitatively similar, but quantitatively much smaller. We also show that the social welfare maximizing replacement rate is lower than the current (post-reform) replacement rate in Germany. However, implementing the optimal unemployment benefit system generates only small welfare gains.
\end{abstract}

JEL: E24, E60, J64, J65

Keywords: Dynamic General Equilibrium, Heterogenous Agents, Human Capital, Labor Market Search, Unemployment Insurance, German Labor Market Reform

\footnotetext{
${ }^{*}$ We are grateful for comments from Wolfgang Franz, Hans Gersbach, Oliver Grimm, Daniel Harenberg, Philip Jung, Alfred Maussner, Ernst-Ludwig von Thadden and numerous seminar participants.

${ }^{\dagger}$ Department of Economics, University of Mannheim, L7, 3-5, 68131 Mannheim, Germany. Email: tkrebs@econ.uni-mannheim.de; Centre for European Economic Research (ZEW), L7, 1, 68131 Mannheim, Germany.

${ }^{\ddagger}$ Address: Centre for European Economic Research (ZEW), L7, 1, 68131 Mannheim, Germany. Email: scheffel@zew.de; Center for Doctoral Studies in Economics (CDSE), University of Mannheim, L7, 3-5, 68131 Mannheim, Germany.
} 


\section{Introduction}

There is considerable evidence that individual households face a substantial amount of labor income risk. ${ }^{1}$ In particular, employed workers face the risk of becoming unemployed. In most countries, the government provides insurance against this type of risk through the payment of unemployment benefits. Other things being equal, the provision of unemployment insurance increases the welfare of risk-averse households. However, unemployment benefits also discourage unemployed households from exerting search effort thereby raising the overall unemployment rate. When employment drops, so does aggregate output. In designing the unemployment insurance system, governments therefore have to weigh the insurance benefits against the costs of distorted incentives. ${ }^{2}$

Although the incentive-insurance tradeoff is already present in a simple one-tiered unemployment benefit system, governments often run multi-tiered unemployment systems with falling benefits schedules in order to deal with the incentive-insurance tradeoff more efficiently. ${ }^{3}$ In 2005 and 2006, the German government implemented two major labor market reforms, the so called Hartz Reforms, in order to establish a more pronounced two-tiered unemployment insurance system to fight the steadily increasing unemployment rate in Germany. The 2005-reform reduced the benefit payments in the second tier, whereas the 2006-reform implemented a sharp reduction in the length of the eligibility period for high benefit payments in the first tier. Both reforms put more emphasis on the incentive effect of the unemployment system. Obviously, such reforms tend to reduce the unemployment rate, but the welfare effect is, due to the above mentioned tradeoff, ambiguous. In this paper, we develop a tractable macroeconomic model, and use a calibrated version of the model to evaluate the quantitative effects of the Hartz Reforms on unemployment, growth, and welfare.

\footnotetext{
${ }^{1}$ Using individual data on labor income dynamics, estimates for the standard deviation of labor income range from 0.15 in Hubbard, Skinner and Zeldes (1995) over 0.19 in Meghir and Pistaferri (2004) up to 0.25 in Storesletten, Telmer and Yaron (2004). Jacobson, LaLonde and Sullivan (1993) focus on the specific issue of labor income dynamics after job displacement and find that long run earnings are on average 25 percent below the pre-displacement rate for long-tenured workers. For a review of the job displacement literature, see KLETZER (1998).

${ }^{2}$ This tradeoff is well known in the literature, e.g. Shavell and Weiss (1979), Hopenhayn and Nicolini (1997), Acemoglu and Shimer (1999) and Lentz (2009).

${ }^{3}$ Much of the theoretical literature on optimal unemployment insurance, e.g. SHAVELL and WEISS (1979) and HopenHAYN and NiCOLINi (1997), supports the idea that falling benefit schedules are optimal. However, recently Shimer and WERning (2007, 2008) challenge this result.
} 
Our model combines the incomplete markets model developed in KREBS $(2003,2006)^{4}$ with the labor market search model introduced by BenhabiB and Bull (1983). As in Krebs (2003, 2006), there are a large number of risk-averse households who invest in risk-free physical capital and risky human capital. Investment in human capital is risky due to wage risk and employment risk. Following BenhaBiB and Bull (1983), unemployed households choose their search effort that determines their re-employment probability in the subsequent period. There is a government that provides unemployment insurance and finances these transfer payments through a consumption tax. Our main theoretical contribution is a tractability result: the equilibrium allocation can be found without knowledge of the underlying wealth distribution, which facilitates the computation of equilibria substantially.

Using our theoretical characterization result, we proceed with the quantitative evaluation of the labor market reforms in Germany. More specifically, we calibrate the model to match the pre2005 German data, and then obtain the quantitative effects of the recent labor market reforms through model simulation. Our main results are as follows. First, the 2005-reform had large employment effects: the equilibrium unemployment rate has been reduced by approximately 1.1 percentage points from 7.5 to 6.4 percent. Second, the drop in unemployment has led to substantial output gains. Third, employed and short-term unemployed households experienced a significant welfare gain, that is, the positive incentive effect dominates the negative insurance effect. However, the long-term unemployed have lost in welfare terms. The effects of the 2006reform are qualitatively similar, but quantitatively much smaller. ${ }^{5}$ Finally, we show that the social welfare maximizing replacement rate is lower than the current (post-reform) replacement rate in Germany. However, implementing the optimal unemployment benefit system generates only small welfare gains.

The rest of the paper is organized as follows. After a short discussion of the related literature in section 2, we develop the economic model in section 3. Section 4 is devoted to the construction of a competitive equilibrium. In section 5 , we calibrate the model to match stylized facts of the

\footnotetext{
${ }^{4}$ On the one hand, this model builds on the extensive literature of human capital based endogenous growth models, e.g. LuCAS (1988) and Jones and MANUELLI (1990), among many others and, on the other hand, KREBS (2003, 2006) relates to the macroeconomic incomplete markets literature, e.g. İMrohoroĞLU (1992), HUGGETT (1993) and AiYAGari (1994).

${ }^{5}$ In other words, the change in the eligibility period implemented in 2006 had only small effects on reemployment probabilities. This result is consistent with the findings of recent empirical studies (see FITZENBERGER and WiLKe (2010) for Germany).
} 
German economy and simulate the respective employment, growth, and welfare effects of the recent labor market reforms. Furthermore, we investigate the robustness of our results with respect to the critical model parameters. Finally, section 6 presents our conclusions.

\section{Related Literature}

In order to model labor markets explicitly, the literature suggests two approaches: the search theoretic approach and the matching function approach. The search theoretic approach assumes that households either receive wage offers that are randomly drawn from a pre-specified distribution, e.g. McCall (1970), Lucas and Prescott (1974) and Luungqvist and Sargent (1998), or that households endogenously decide on their search effort which then determines their re-employment probability in the subsequent period, e.g. BenHABIB and BuLL (1983) and LENTZ (2009). Our paper follows in the tradition of the search literature and is most closely related to LENTz (2009), who extends AiYAgari (1994) by allowing individual households to choose their search effort. However, in contrast to Lentz (2009), we consider a tractable framework that allows us to find (almost) closed-form solutions. Moreover, we take a general equilibrium perspective and also analyze the long-run growth effects of labor market reforms.

The matching function approach, based on PHeLPs (1968) and in particular PISSARIDES (1979), has the advantage of providing a detailed analysis of the "demand side" of the labor market. ${ }^{6}$ Like the search theoretic approach, these models are often based on risk neutrality such that the insurance effect of unemployment benefit payments cannot be analyzed. However, work by ACEmoglu AND Shimer $(1999,2000)$ has explicitly dealt with risk aversion in a matching model and shown that unemployment insurance can lead to productivity/output gains. More recently, several papers have integrated the incomplete-market paradigm with the matching function approach (Costain and Reiter (2005), NAKajima (2008), and Krusell, Mukoyama and ŞAHIN (2009)) and addressed various economic issues, but none of these papers has developed a tractable framework for policy analysis. Put differently, the complicated ex-post heterogeneity of households forces the authors to use time-consuming numerical methods in order to simulate the equilibria of the economy. ${ }^{7}$

\footnotetext{
${ }^{6}$ For a detailed overview of the matching model approach, see PISSARIDES (2000).

${ }^{7}$ Costain and Reiter (2005) and NAKAJima (2008) focus on the insurance effect of unemployment benefit
} 
Our paper also relates to the extensive literature of optimal unemployment insurance that has explicitly addressed the tradeoff between insurance and incentives in an asymmetric information framework.(Shavell and Weiss (1979) and Hopenhayn and Nicolini (1997)). Papers in this literature have usually not modelled the consumption-saving choice of individual households, but in a series of papers ShImer and Werning $(2007,2008)$ have been able to characterize analytically the optimal unemployment benefit system using a CARA-utility specification and a partial equilibrium setting.

Finally, there is a large empirical literature on policy reform evaluation that analyzes the effect of various labor market reforms on the unemployed using micro-level data (see FRANZ (2009) and our discussion in section 5.1 for a survey). In a certain sense, papers in this literature also deal with the interaction of labor market reform and labor market risk (long-term consequences of unemployment). However, work in this literature usually does not take into account any effect of labor market reform on labor demand and wages, something that is arguably of first-order importance when the labor market reform affects a large number of workers (macroeconomic analysis). By contrast, some of the work in the applied general equilibrium literature (see, for example, Böhringer, Boeters, and Feil (2005) and Immervold, Kleven, Kreiner, and SAEz (2007)) explicitly deals with such labor market effects of policy reform, and some interesting applications of this approach to Germany have been done in Franz, Gürtzgen, Schubert, and Clauss (2007). However, this work has neither taken into account income risk nor considered the interaction of labor, capital, and goods markets, two issues that will take center stage in our analysis.

\section{The Economy}

\subsection{Households}

Consider a discrete-time, infinite-horizon, search model of the labor market with one nonperishable all-purpose good that can be either consumed or invested. There is a continuum

payments, but in the absence of endogenous search effort choices in their models, the provision of more unemployment insurance does not discourage households from search. Put differently, in designing the unemployment insurance system, the government in their models does not face the tradeoff between offering insurance, on one side, and providing incentives, on the other. LAUNOV and WÄLDE (2010) also present a tractable macro model with income risk and search/matching, but they do not allow workers to save. 
of ex-ante identical, infinitely-lived households with unit mass. Let $S=S_{1} \times S_{2}$ denote the space of stochastic states, where $s_{1 i t} \in S_{1}$ is the current employment state of household $i$, and $s_{2 i t} \in S_{2}$ denotes an i.i.d. depreciation shock to human capital.

Preferences are time-separable and each household receives utility from consumption $c_{i t}$ and disutility from search effort $l_{i t}$. By choosing the search intensity, unemployed agents directly determine their next-period re-employment probability. The one-period utility function is separable in consumption and search. Specifically, assume

$$
u\left(c_{i t}, l_{i t}\right)=\log c_{i t}-v\left(l_{i t}\right)-\mathbf{1}_{s_{1 i t}=u} \omega
$$

where $v\left(l_{i t}\right)$ denotes the disutility from search, satisfying $v(0)=0$ and $v^{\prime}\left(l_{i t}\right)>0$, and $\omega$ is the disutility of being unemployed. The indicator function $\mathbf{1}_{x}$ is one when statement $x$ is true and zero otherwise. Future utility is discounted by the time discount factor $\beta$.

Let $k_{i t}$ and $h_{i t}$ denote the stocks of physical and human capital held by household $i$. Employed households receive capital and labor income, $r_{k t} k_{i t}$ and $r_{h t} h_{i t}$, with $r_{k t}$ and $r_{h t}$ denoting the (gross) return to physical and human capital, respectively. We assume that the income net of depreciation of unemployed households is proportional to total asset holdings. Specifically, income is given by $b_{t}^{q}\left(k_{i t}+h_{i t}\right)$, where benefit entitlements can be either high, $q=h$, or low, $q=\ell$. This assumption guarantees that the unemployed will not shift resources from physical to human capital as a response to a change of the benefit rate so that output effects that are solely based on the unemployed's shift from unproductive human capital to productive physical capital are excluded. Furthermore, as we will show, every household chooses the same portfolio of physical and human capital in equilibrium. This excludes substantial negative human capital investment and thus allows a straightforward interpretation of the benefit rate $b_{t}^{q}$ as unemployment benefit. ${ }^{8}$ The households use their net income and their current wealth position to buy consumption, which is taxed at rate $\tau_{c t}$, and next period physical and human capital stock.

\footnotetext{
${ }^{8}$ There is also a different interpretation of the assumption that income of unemployed households is given by $b_{t}^{q}\left(k_{i t}+h_{i t}\right)$ : The government pays unemployment benefits $\tilde{b}_{t}^{q} h_{i t}$ and seizes a fraction $\rho_{t}^{q}$ of the unemployed's physical capital income and uses this revenue as an additional source to finance the unemployment benefit net depreciation. The unemployed's capital income is thus taken into account when determining the unemployment compensation. Total income, net of depreciation, of the unemployed is given by $\left(\left(1-\rho_{t}^{q}\right) r_{k t}-\delta_{k}\right) k_{i t}+\left(\tilde{b}_{t}^{q}-\right.$ $\left.\delta_{h}\left(s_{2 i t}\right)\right) h_{i t}$. For simplicity, we assume that the government sets $\tilde{b}_{t}^{q}$ and $\rho_{t}^{q}$ such that $\tilde{b}_{t}^{q}-\delta_{h}\left(s_{2 i t}\right)=\left(1-\rho_{t}^{q}\right) r_{k t}-\delta_{k}$ and define $b_{t}^{q}=\tilde{b}_{t}^{q}-\delta_{h}\left(s_{2 i t}\right)$. The unemployed's income thus simplifies to $b_{t}^{q}\left(k_{i t}+h_{i t}\right)$.
} 
Each household $i$ chooses a complete contingent plan $\left\{c_{i t}, k_{i, t+1}, h_{i, t+1}, l_{i t}\right\}_{t=0}^{\infty}$ in order to maximize its lifetime utility. Specifically, the optimization problem reads

$$
\max _{\left\{c_{i t}, k_{i, t+1}, h_{i, t+1}, l_{i t}\right\}_{t=0}^{\infty}}\left\{U=\mathbb{E}_{S}\left[\sum_{t=0}^{\infty} \beta^{t}\left(\log c_{i t}-v\left(l_{i t}\right)-\mathbf{1}_{s_{1 i t}=u} \omega\right)\right]\right\}
$$

subject to

$$
\begin{aligned}
&\left(1+\tau_{c t}\right) c_{i t}+k_{i, t+1}+h_{i, t+1}=\left\{\begin{array}{l}
\left(1+r_{k t}-\delta_{k}\right) k_{i t}+\left(1+r_{h t}-\delta_{h}\left(s_{2 i t}\right)\right) h_{i t}, \quad \text { for } s_{1 i t}=e \\
\left(1+b_{t}^{q}\right)\left(k_{i t}+h_{i t}\right), \quad \text { otherwise, } q \in\{h, l\}
\end{array}\right. \\
& k_{i, t+1} \geq 0 \\
& h_{i, t+1} \geq 0
\end{aligned}
$$

where $\delta_{k}$ is the depreciation rate of physical capital and $\delta_{h}\left(s_{2 i t}\right)$ denotes the stochastic depreciation rate on human capital. For convenience, the subscript of the expectation operator indicates the space with respect to which we take the expectation.

We now discuss the space of stochastic states $S$ (in contrast to the individual physical and human capital holdings $\left\{k_{i t}, h_{i t}\right\} \in \mathbb{R}_{+}^{2}$ that can be directly determined by households in the previous period) and the underlying state transition probabilities in more detail. Households are either employed, $s_{1 i t}=e$, or unemployed. Unemployed agents are, on the one hand, either good or bad job seekers $\{g, b\}$, and, on the other hand, either entitled to high or low unemployment benefits $\{h, l\}$. Hence, we have to distinguish between four different unemployment states: households with good search skills that are entitled to high or low unemployment benefits, $s_{1 i t}=u^{g \hbar}$ and $s_{1 i t}=u^{g \ell}$, and households with bad job search skills who can as well be entitled to either high or low unemployment benefits, $s_{1 i t}=u^{6 \hbar}$ and $s_{1 i t}=u^{6[}$. Taken together, the total space of employment states is given by $S_{1}=\left\{e, u^{g h}, u^{g l}, u^{6 \hbar}, u^{6 \epsilon}\right\}$.

The employment state transition is as follows: With probability $\sigma_{x}$, employed agents lose their job, they become unemployed and are initially both, eligible for high unemployment benefit and good job seekers. Unemployed agents exert search effort $l_{i t}$ and they find a new job in $t+1$ with probability $\pi^{j}\left(l_{i t}\right)$, for $j \in\{g, 6\}$. By definition, bad job seekers that exert the same search effort as the good ones will nevertheless have a lower probability of re-employment. If, job search 
is not successful, they will lose, if it has not already happened before, their entitlement to high benefits with probability $\sigma_{b t}$ and their good search skills with exogenously given probability $\sigma_{s} \cdot{ }^{9}$ Following Shimer and Werning (2006), we interpret the shock to the search technology as depreciation of search skills. For example, search skills depreciate when households have finished searching for a job in the easily accessible proximity of their own social network and now have to consider jobs outside their network. Note that while households take $\sigma_{b t}$ as exogenous to their optimization problem, the government chooses $\sigma_{b t}$ as part of its labor market policy. This specification of the state transition process implies that the longer the unemployment spell, the higher the probability that households have lost their entitlement to high benefit payments and the higher the probability that households have become bad job seekers.

In addition to the employment state, there is a general independent and identical distributed depreciation shock $s_{2 i t} \in S_{2}$ on human capital. This shock is used to capture earning volatility due to e.g. promotion or changes in the working conditions. Clearly, this shock only applies to employed households. In contrast to the employment shock, this depreciation shock constitutes a permanent income shock. With $\bar{\delta}_{h}$ denoting the deterministic part of human capital depreciation, the total depreciation rate of human capital reads

$$
\delta_{h}\left(s_{2 i t}\right)=\bar{\delta}_{h}+\mathbf{1}_{s_{1 i t}=e} s_{2 i t}
$$

Clearly, only the current employment state has predictive power for the state in the next period: $\pi\left(s_{i, t+1} \mid s_{i t}\right)=\pi\left(s_{i, t+1} \mid s_{1 i t}\right)$.

\subsection{Production}

The production sector consists of a continuum of identical firms with neoclassical production function that uses physical and human capital to produce the all-purpose good that can be either consumed or invested. The production sector is competitive and can be represented by an aggregate firm whose profit function reads

$$
\Pi\left(K_{t}, H_{t}^{e}\right)=F\left(K_{t}, H_{t}^{e}\right)-r_{k t} K_{t}-r_{h t} H_{t}^{e}
$$

\footnotetext{
${ }^{9}$ The detailed employment state transition matrix is deferred to the appendix.
} 
$K_{t}$ denotes the aggregate amount of physical capital in the economy and $H_{t}^{e}$ is the aggregate amount of human capital used in the production sector.

\subsection{Government}

The government pays out unemployment benefits $\mathbb{E}_{I}\left[b_{t}^{q}\left(k_{i t}+h_{i t}\right) \mid s_{1 i t}=u^{q}\right]$, collects consumption taxes, $\tau_{c t} \mathbb{E}_{I}\left[c_{i t}\right]$, and seizes the unemployed's capital income, $r_{k t} \mathbb{E}_{I}\left[k_{i t} \mid s_{1 i t}=u^{q}\right]$ for $q \in\{g, b\} \times\{h, \zeta\}$. We assume that the government runs a balanced budget in every period. Thus, the government's budget constraint reads

$$
\tau_{c t} \mathbb{E}_{I}\left[c_{i t}\right]+r_{k t} \mathbb{E}_{I}\left[k_{i t} \mid s_{1 i t}=u^{q}\right]=\mathbb{E}_{I}\left[b_{t}^{q}\left(k_{i t}+h_{i t}\right) \mid s_{1 i t}=u^{q}\right]
$$

In addition to the consumption $\operatorname{tax}\left\{\tau_{c t}\right\}_{t=0}^{\infty}$ and the benefit rates $\left\{b_{t}^{h}, b_{t}^{c}\right\}_{t=0}^{\infty}$, the government also chooses the expected entitlement period to high benefit payments via $\left\{\sigma_{b t}\right\}_{t=0}^{\infty}$, which enters the government's budget constraint through the expectation operator. From now on, we restrict to stationary labor market policies in the sense that $\left\{b_{t}^{h}, b_{t}^{\ell}, \sigma_{b t}\right\}_{t=0}^{\infty}=\left(b^{h}, b^{\ell}, \sigma_{b}\right)$.

\section{Equilibrium}

In order to construct the equilibrium, we follow KREBS (2003) and transform the optimization problem into a portfolio choice problem. Define total wealth $w_{i t} \equiv k_{i t}+h_{i t}$ and the portfolio share of physical capital $\theta_{i t} \equiv \frac{k_{i t}}{k_{i t}+h_{i t}}$. Equipped with these definitions, the household's budget constraint and the law of motion for physical and human capital simplifies to

$w_{i, t+1}= \begin{cases}{\left[1+\theta_{i t}\left(r_{k t}-\delta_{k}\right)+\left(1-\theta_{i t}\right)\left(r_{h t}-\delta_{h}\left(s_{2 i t}\right)\right)\right] w_{i t}-\left(1+\tau_{c t}\right) c_{i t}} & \text { for } s_{1 i t}=e \\ {\left[1+b^{q}\right] w_{i t}-\left(1+\tau_{c t}\right) c_{i t}} & \text { otherwise, } q \in\{\hbar, \mathcal{L}\}\end{cases}$

The terms in square brackets denote the return to total wealth that we conveniently define as $\left[1+r\left(\theta_{i t}, s_{i t} ; r_{k t}, r_{h t}\right)\right]$. For employed agents, this return is the portfolio weighted net return to physical and human capital. In contrast, unemployed agents just receive an, at least for the household perspective, exogenous return $b^{q}, q \in\{h, l\}$. Clearly, the return to wealth for the employed households depends on the individual portfolio choice, whereas the return for 
unemployed agents does not. With these definitions, the household's budget constraint simplifies further to

$$
w_{i, t+1}=\left[1+r\left(\theta_{i t}, s_{i t} ; r_{k t}, r_{h t}\right)\right] w_{i t}-\left(1+\tau_{c t}\right) c_{i t}
$$

Instead of $\left\{c_{i t}, x_{k i t}, x_{h i t}, l_{i t}\right\}_{t=0}^{\infty}$, households now directly choose $\left\{c_{i t}, \theta_{i, t+1}, w_{i, t+1}, l_{i t}\right\}_{t=0}^{\infty}$ subject to the flow budget constraint (1). A competitive equilibrium is defined as follows:

Definition 1 (Competitive Equilibrium for Given Labor Market Policy).

A competitive equilibrium for given labor market policy $\left(b^{h}, b^{l}, \sigma_{b}\right)$ is

1. a sequence $\left\{K_{t}, H_{t}^{e}\right\}_{t=0}^{\infty}$ that maximizes the firm's profit for a given sequence of factor prices $\left\{r_{k t}, r_{h t}\right\}_{t=0}^{\infty}$

2. a sequence $\left\{c_{i t}, \theta_{i, t+1}, w_{i, t+1}, l_{i t}\right\}_{t=0}^{\infty}$ that solves agent $i$ 's maximization problem for a given sequence of factor prices $\left\{r_{k t}, r_{h t}\right\}_{t=0}^{\infty}$, idiosyncratic shocks $\left\{s_{i t}\right\}_{t=0}^{\infty}$ and consumption tax rates $\left\{\tau_{c t}\right\}_{t=0}^{\infty}$;

3. a sequence $\left\{r_{k t}, r_{h t}\right\}_{t=0}^{\infty}$ that satisfies market clearing on the input factor market, $\mathbb{E}_{I}\left[k_{i t}\right]=$ $K_{t}$ and $\mathbb{E}_{I}\left[h_{i t} \mid s_{1 i t}=e\right]=H_{t}^{e} ;$ and

4. a sequence of consumption tax rates that satisfies the balanced budget constraint of the government $\left\{\tau_{c t}\right\}_{t=0}^{\infty}$.

From now on, we focus on a stationary equilibrium as defined in the next proposition:

Definition 2 (Stationary Equilibrium).

A competitive equilibrium for given labor market policy is stationary if

1. the returns to physical and human capital are stationary, $r_{k t}=r_{k}$ and $r_{h t}=r_{h}$,

2. the tax policy is stationary, $\tau_{c t}=\tau_{c}$, and

3. the flow into the different employment states is equal to the flow out of them.

Let us start with the firm's optimization problem. Due to competitive markets, the usual marginal product conditions for profit maximization apply. Define the aggregate capital-to-labor 
ratio that is used in production $\tilde{k}_{t}=\frac{K_{t}}{H_{t}^{e}}$ and define the production technology in intensive form $f\left(\tilde{k}_{t}\right)=F\left(\tilde{k}_{t}, 1\right)$. The conditions for profit maximization in the stationary equilibrium then read

$$
\begin{aligned}
& r_{k}=f^{\prime}\left(\tilde{k}_{t}\right) \\
& r_{h}=f\left(\tilde{k}_{t}\right)-\tilde{k}_{t} f^{\prime}\left(\tilde{k}_{t}\right)
\end{aligned}
$$

Stationarity of the factor prices immediately reveals $\tilde{k}_{t}=\tilde{k}$. Thus, the total investment return can be more compactly written as $r\left(\theta_{i t}, s_{i t} ; r_{k}, r_{h}\right)=r\left(\theta_{i t}, s_{i t} ; \tilde{k}\right)$.

We now consider the maximization problem of the households. The Bellman equation associated with the household's optimization problem is

$$
V\left(\theta_{i t}, w_{i t}, s_{i t}\right)=\max _{c_{i t}, \theta_{i, t+1}, w_{i, t+1}, l_{i t}}\left\{\log c_{i t}-v\left(l_{i t}\right)-\mathbf{1}_{s_{1 i t}=u} \omega+\beta \mathbb{E}_{S}\left[V\left(\theta_{i, t+1}, w_{i, t+1}, s_{i, t+1}\right]\right\}\right.
$$

subject to the flow budget constraint (1). The first-order conditions with respect to $w_{i, t+1}, \theta_{i, t+1}$ and $l_{i t}$ are

$$
\begin{aligned}
\frac{1}{c_{i t}}= & \beta \mathbb{E}_{S}\left[\frac{1+r\left(\theta_{i, t+1}, s_{i, t+1} ; \tilde{k}\right)}{c_{i, t+1}}\right] \\
0= & \mathbb{E}_{S}\left[\frac{\left(r_{k}-\delta_{k}\right)-\left(r_{h}-\delta_{h}\left(s_{2 i, t+1}\right)\right)}{c_{i, t+1}}\right] \\
v^{\prime}\left(l_{i t}\right)= & \beta \pi^{\prime}\left(l_{i t}\right) \mathbb{E}_{S_{2}}\left[V\left(\theta_{i, t+1}, w_{i, t+1}, s_{1 i, t+1}=e, s_{2 i, t+1}\right)-\right. \\
& \left.\sum_{q \in\{g, 6\} \times\{h, l\}} \pi\left(s_{1 i, t+1}=u^{q} \mid s_{1 i t}\right) V\left(\theta_{i, t+1}, w_{i, t+1}, s_{1 i, t+1}=u^{q}, s_{2 i, t+1}\right)\right]
\end{aligned}
$$

The Euler equation (5) has the usual interpretation that the household's utility loss today of investing one more unit of the consumption good is equal to the utility gain tomorrow of doing so. The intra-temporal first-order condition (6) states that the household must be indifferent between investing one more unit into physical capital and one more unit into human capital. Finally, equation (7) requires that the utility loss today of searching one more unit is equal to the expected utility gain tomorrow of doing so. Any plan $\left\{c_{t}, \theta_{t+1}, w_{t+1}, l_{t}\right\}_{t=0}^{\infty}$ that solves the system of first-order conditions equations (5) to (7), the budget constraint (1) and 
the corresponding transversality condition, is a solution to the household's constrained utility maximization problem. ${ }^{10}$ It is easy to verify that the consumption and saving functions

$$
\begin{aligned}
c_{i t} & =\frac{1-\beta}{1+\tau_{c}}\left(1+r\left(\theta_{i t}, s_{i t} ; \tilde{k}\right)\right) w_{i t} \\
w_{i, t+1} & =\beta\left(1+r\left(\theta_{i t}, s_{i t} ; \tilde{k}\right)\right) w_{i t}
\end{aligned}
$$

jointly solve the budget constraint (1) and the Euler equation (5). Using these policy functions with the method of guess and verify, we can show that

Proposition 1. The value function $V\left(\theta_{i t}, w_{i t}, s_{i t}\right)$ that solves the respective Bellman equation is given by

$$
V\left(\theta_{i t}, w_{i t}, s_{i t}\right)=\frac{1}{1-\beta} \log \left[\left(1+r\left(\theta_{i t}, s_{i t} ; \tilde{k}\right)\right) w_{i t}\right]+B\left(s_{1 i t}\right)
$$

where $B\left(s_{1 i t}\right)$ solves the Bellman equation in intensive form

$$
\begin{aligned}
B\left(s_{1 i t}\right)=\max _{\theta_{i, t+1}, l_{i t}}\left\{\log \frac{1-\beta}{1+\tau_{c}}+\right. & \frac{\beta}{1-\beta} \log \beta-v\left(l_{i t}\right)-\mathbf{1}_{s_{1 i t}=u} \omega \\
& \left.\beta \mathbb{E}_{S}\left[\frac{1}{1-\beta} \log \left(1+r\left(\theta_{i, t+1}, s_{i, t+1} ; \tilde{k}\right)\right)+B\left(s_{1 i, t+1}\right)\right]\right\}
\end{aligned}
$$

Proof. See appendix.

Using the consumption policy (8), the first-order conditions with respect to $\theta_{i, t+1}$ simplify to

$$
0=\mathbb{E}_{S_{2}}\left[\frac{\left(r_{k}-\delta_{k}\right)-\left(r_{h}-\delta_{h}\left(s_{2 i, t+1}\right)\right)}{1+r\left(\theta_{i, t+1}, s_{i, t+1} ; \tilde{k}\right)}\right]
$$

Note that since the return to wealth for unemployed households does not depend on their individual portfolio composition, the first-order condition with respect to the portfolio choice, equation (12), is independent of the transition probabilities and thus, independent of the current employment state $s_{1 i t}$ and the search effort $l_{i t}$. Moreover, this condition is also independent of

\footnotetext{
${ }^{10}$ In proposition 1 , we solve for the value function that is associated with the plan $\left\{c_{i t}, w_{i, t+1}, \theta_{i t}, l_{i t}\right\}_{t=0}^{\infty}$. The value function is finite and thus, the transversality condition holds.
} 
the current portfolio share and the household's current wealth, leading to the conclusion that every agent chooses the same portfolio, independent of his individual shock history and wealth. This clearly defines a policy function $\theta_{i, t+1}=\theta(\tilde{k})$.

The consumption policy (8) and the Bellman equation in intensive form (16) help to transform the first-order condition with respect to the search effort decision into

$$
\begin{aligned}
& \frac{v^{\prime}\left(l_{i t}\right)}{\beta \pi^{\prime}\left(l_{i t}\right)}=\mathbb{E}_{S_{2}}\left[\left(\frac{\log \left(1+r\left(\theta_{i, t+1}, s_{1 i, t+1}=e, \tilde{k}\right)\right)}{1-\beta}+B\left(s_{1 i, t+1}=e\right)\right)-\right. \\
& \left.\quad \sum_{q \in\{g, 6\} \times\{h, l\}} \pi\left(s_{1 i, t+1}=u^{q} \mid s_{1 i t}\right)\left(\frac{\log \left(1+r\left(\theta_{i, t+1}, s_{1 i, t+1}=u^{q}, \tilde{k}\right)\right)}{1-\beta}+B\left(s_{1 i, t+1}=u^{q}\right)\right)\right]
\end{aligned}
$$

Observe that this condition is independent of wealth, the current portfolio and the current realization of the i.i.d. depreciation shock $s_{2 i t}$. Thus, conditional on the employment status, $s_{1 i t}$, every household chooses the same search intensity. This defines a function $l_{i t}=l\left(s_{1 i t}=u^{q} ; \tilde{k}\right)$, for $q=\{n, s\} \times\{h, l\}$. Our result is closely related to Shimer and Werning (2008), who combine an AIYAGARI (1994) model with MCCALL's (1970) search model of the labor market. Under CARA-preferences, they show that the choice of the reservation wage (which is equivalent to the search effort choice in our model) is wealth-independent with strong implications for the optimal unemployment benefit scheme. The wealth independence in our model, however, is based on the combination of more general homothetic preferences and disposable income which is linear homogenous in the agent's asset holdings. Market clearing on the input factor market requires that the households' supply of physical and human capital is consistent with the firm's demand for the two input factors. Thus, market clearing satisfies

$$
\tilde{k}=\frac{\mathbb{E}_{I}\left[\left(1-\theta\left(s_{1 i t} ; \tilde{k}\right)\right) w_{i t} \mid s_{1 i t}=e\right]}{\mathbb{E}_{I}\left[\theta\left(s_{1 i t} ; \tilde{k}\right) w_{i t}\right]}
$$

Although in equilibrium aggregate wealth grows infinitely at a constant rate, the wealth of type $s_{1 t}$ households relative to aggregate wealth is constant. Hence, as will be shown in the appendix, the market clearing condition (14) depends on the wealth ratios but is independent of the absolute wealth level.

Finally, using the household's policy functions and market clearing, it is easy to verify that the government's budget constraint is independent of the absolute wealth level. Moreover, since 
the policy functions for saving, portfolio choices and search decisions, as well as the market clearing condition, are independent of the consumption tax rate, it is trivial to choose the consumption tax rate $\tau_{c}$ such that the government budget is satisfied. In particular, the choice of the consumption tax rate does not distort the equilibrium allocations.

Summing up:

Proposition 2. A stationary competitive equilibrium for given labor market policy, $\left(\phi^{h}, \phi^{l}, \sigma_{b}\right)$, is characterized by

1. The firms' problem satisfies the usual marginal product conditions, equations (2) and (3).

2. The households' consumption and saving policies are linear homogenous in wealth and given by equations (8) and (9). Conditional on the employment state, every agent chooses the same wealth independent portfolio and search effort decision. In particular, the portfolio choice and search effort decision jointly solve equations (12) and (13).

3. Market clearing satisfies (14) and is independent of the absolute wealth level in the economy.

4. The consumption tax rate does not distort the above characterized equilibrium and solves the government's budget constraint.

Observe that despite the ex-post heterogeneity, which makes solutions to dynamic general equilibrium models very complicated and time-consuming, we found a very simple solution within our framework.

\section{Quantitative Analysis}

\subsection{Calibration}

We calibrate our model economy such that the equilibrium is consistent with quarterly German data of the pre-reform period. The pre-2005 system was characterized by a rather long period of Unemployment Benefit entitlements and an essentially unlimited means-tested Unemployment Assistance after the eligibility to Unemployment Benefit entitlements expired. Unemployment Benefit was between 60 and 67 percent of the previous net income whereas Unemployment 
Table 1: Calibration - Exogenous Parameters

\begin{tabular}{clc}
\hline \hline PARAMETER & DESCRIPTION & VALUE \\
\hline $\begin{array}{ll}\text { PREFERENCES } \\
A\end{array}$ & parameter of disutility of search & 25 \\
PRODUCTION & & \\
$\alpha$ & capital share & 0.3600 \\
DEPRECIATION & AND DEPRECIATION SHOCKS & \\
$\delta_{k}$ & depreciation rate: physical capital & 0.0150 \\
$\delta_{h}$ & depreciation rate: human capital if employed & 0.0150 \\
$\mu_{s_{2 t}}$ & expectation of iid shock & 0 \\
$\sigma_{s_{2 t}}$ & standard deviation of iid shock & 0.1500 \\
LABOR MARKET AND TRANSITION RATES & \\
$b^{h}$ & unemployment benefit rate: high entitlement & 0.6900 \\
$b^{l}$ & unemployment benefit rate: low entitlement & 0.6900 \\
$\sigma_{x}$ & job separation probability & 0.0300 \\
$\sigma_{b}$ & probability of loosing high benefit & 0.1554 \\
$\sigma_{s}$ & arrival rate of search technology shock & 0.2500 \\
\hline \hline
\end{tabular}

Assistance lay between 53 and 57 percent of previous net income. ${ }^{11}$ If benefit payments were below the minimum level of subsistency, Social Assistance was used to meet the additional need. Taking this into account, the OECD (2006) calculates effective average net replacement rates of about 69 percent for both, Unemployment Benefit and Unemployment Assistance. Hence, the two-tiered unemployment insurance system was effectively a one-tiered system. Based on Schmitz And Steiner (2007), we calculate an average eligibility period for high benefit payments of 19.3 months which translates into $\sigma_{b}=0.1554 .{ }^{12}$ This accomplishes the calibration of the government's pre-reform policy parameters.

Having already calibrated $\sigma_{b}$, we now focus on the determination of the remaining state transition rates: Since our setup abstracts from non-participation in the labor market, we have

\footnotetext{
${ }^{11}$ See for example Schmitz and Steiner (2007).

${ }^{12}$ In particular, we assume a uniform distribution of households aged between 25 and 64 years and calculate the average (maximal) entitlement period for this age group.
} 
to adjust the employment-to-unemployment flows by the employment-to-non-participation flows. However, the employment-to-non-participation flows also include old households who decide to retire early, young households who return to school in order to accomplish their formal education and women who decide to take a maternity leave. These cases cannot be counted as job loss in a narrow sense, and if we would include them, our job loss rate would be upward biased. To avoid these issues, we only take the transition rates from employment to unemployment and from employment to non-participation of 25 to 55 year old males as the job loss rate. Using the calculations by BACHMANN (2005) both rates add up to approximately one percent per month which yields $\sigma_{x}=0.03$ per quarter. JUNG and KUHN (2010) find transition rates in the same order of magnitude. For simplicity, we associate the search skill depreciation shock with long-term unemployment, which is usually defined as an unemployment spell of at least one year. This yields a probability of losing job search skills of $\sigma_{s}=0.25$. For the job search technology, we follow LENTz (2009) and use an exponential specification

$$
\pi^{j}\left(l_{i t}\right)=1-\mathrm{e}^{-\lambda^{j} l_{i t}}, \text { for } j \in\{g, b\}
$$

where $\lambda^{g}>\lambda^{6}$. The search technology parameters are determined such that the equilibrium unemployment rate is 7.5 percent and the equilibrium share of long-term unemployed households to total unemployed households is 42 percent. The calibration values of the search technology parameters depend on the equilibrium search effort which in turn depends on the specification of the disutility search.

The preference parameters are calibrated as follows: As in HOPENHAYN and NICOLINI (1997) or Shimer and Werning (2006, 2007, 2008), disutility of search is linear in search effort

$$
v\left(l_{i t}\right)=-A l_{i t}
$$

In equilibrium, the parameter $A$ is not separately identified from the parameters of the search technology $\lambda^{g}$ and $\lambda^{6}$. Consequently, there is one degree of freedom such that we can set the scaling parameter to a numerically convenient value of $A=25$. This implies $\lambda^{g}=7.2606$ and $\lambda^{6}=2.9999$ in order to make the equilibrium match our calibration targets. The disutility of being unemployed, $\omega$, is calibrated to match the point elasticity of the job finding rate 
with respect to benefit payments. Empirically, this elasticity is hard to pin down, because the data sets either do not include the required information to construct a precise measure of benefit payments (IAB data), or there are too few observations to get reliable results (GSOEP). Addison, Centeno and Portugal (2008) use a structural search model and the European Community Household Panel (ECHP) to estimate the elasticity for several European countries, and for Germany they find values between $\eta_{\theta, b}=-1.66$ and $\eta_{\theta, b}=-1.14$. For the US, MEYER and MoK (2007) use a quasi-experimental setup in which the maximum weekly benefit payments in New York State were raised. Their approach allows the construction of different control groups of households leading to substantial variation in the data to get reliable results. ${ }^{13}$ They find that for the US, increasing the benefit rate by 1 percent leads to an increase in benefit duration by 0.21 percent, and translating this number into an elasticity of the re-employment probability with respect to benefit payments yields approximately $\eta_{\theta, b}=-0.2$. Clearly, the benefit level in the US is much lower than in Germany, which implies that the elasticity in Germany has to be higher in absolute terms. However, Addison, Centeno and Portugal (2008) also estimate the respective elasticity for the UK, which has labor market institutions comparable to the US. For the UK, they find elasticities between $\eta_{\theta, b}=-0.62$ and $\eta_{\theta, b}=-0.36$, in absolute terms higher that the estimates by MEYER and MoK (2007) for the US, indicating that the estimates for Germany are upward biased, in absolute terms. For this reason, we take the lower bound, $\eta_{\theta, b}=-1.14$ for the benchmark calibration, yielding $\omega=0.2668$. Since the elasticity has a key role in determining the effect of the labor market reforms on the aggregate unemployment rate, we will run a sensitivity analysis for lower elasticities as well. Finally, the time-discount factor $\beta$ is set such that the aggregate private saving rate in equilibrium is 20 percent. This yields $\beta=0.9799$.

We calibrate the depreciation rates to $\delta_{k}=\delta_{h}=0.015$, which is approximately 6 percent per annum. For physical capital, this value lies within the range suggested by the literature. For human capital, Browning, Hansen and Heckman (1999) find annual depreciation rates between 0 and 4 percent. Accounting for the infinite horizon structure in our model, we have

\footnotetext{
${ }^{13}$ In particular, households can be separated into three groups: i.) those who are not affected by this policy since they were not eligible to the maximum weekly benefit payments under the old regime, ii.) those who are partially affected in the sense that their new weekly benefit payments lie between the old and the new maximum weekly benefit level and iii.) those who are now eligible for the maximum benefit level under the new regime.
} 
to add an additional depreciation of 2 percent. Thus, a human capital depreciation rate of 6 percent corresponds to an upper bound of reasonable values suggested in the literature. The i.i.d. depreciation shock to human capital is normally distributed with mean zero and standard deviation $\sigma_{s_{2 t}}=0.15$, which, together with the employment shocks and loss of job specific skills, implies a standard deviation of labor income in equilibrium that is in line with micro-evidence for Germany, estimated by KREBS and YAO (2009).

Table 2: Calibration - Endogenous Parameters

\begin{tabular}{llc}
\hline \hline PARAMETER & DESCRIPTION & VALUE \\
\hline PREFERENCES & & 0.9799 \\
$\beta$ & time preferences & 0.2668 \\
$\omega$ & disutility of being unemployed & \\
PRODUCTION & & 0.0794 \\
$z$ & productivity & \\
LABOR MARKET AND TRANSITION RATES & 7.2606 \\
$\lambda^{g}$ & search technology parameter: good job seeker & 2.9999 \\
$\lambda^{6}$ & search technology parameter: bad job seeker & \\
PARAMETERS & ARE CHOSEN TO MATCH & 0.2000 \\
& aggregate saving rate & 0.0051 \\
& aggregate quarterly consumption growth rate & 0.0750 \\
& unemployment rate & 0.42 \\
& share of long-term unemployment & -1.1400 \\
& average benefit elasticity of reemployment probability & \\
\hline \hline
\end{tabular}

Finally, the production technology is Cobb-Douglas

$$
F\left(K_{t}, H_{t}^{e}\right)=z\left(K_{t}\right)^{\alpha}\left(H_{t}^{e}\right)^{1-\alpha}
$$

with the capital share of output set to $\alpha=0.36$. The scaling parameter of the production technology is chosen such that the annual equilibrium growth rate of aggregate consumption is 2 percent. This gives $z=0.0794$. 


\subsection{Growth and Welfare Effect of German Labor Market Reform}

The first reform, which was implemented in January 2005, replaced the Unemployment Assistance with Unemployment Benefit II, which requires tighter means tests and is independent of previous earnings. ${ }^{14}$ Mapping this new system into our model (where unemployment benefits depend on the stock of human capital), average benefit payments in the second tier decrease substantially to about 45 percent of previous net earnings. The regulations of the second reform became binding in February 2006. The eligibility period for Unemployment Benefit $I^{15}$ was reduced for all unemployed households, and a particularly strong reduction was implemented for older unemployed agents. Based on Schmitz and Steiner (2007) we calculate that the average eligibility period dropped from 19.3 to 13.5 months, thus $\sigma_{b}$ increases from 0.1554 to 0.2222 .

Table 3: Macroeconomic Effects of the Labor Market Reforms

\begin{tabular}{lccc}
\hline \hline & BENCHMARK & REFORM 1 & REFORM 2 \\
\hline unemployment rate & $7.50 \%$ & $6.38 \%$ & $6.25 \%$ \\
share of long-term unemployment & $42.0 \%$ & $32.8 \%$ & $31.7 \%$ \\
annualized growth rate & $2.00 \%$ & $2.06 \%$ & $2.08 \%$ \\
level effect on consumption $^{1}$ & $0.00 \%$ & $0.96 \%$ & $1.12 \%$ \\
consumption tax rate & $3.66 \%$ & $2.69 \%$ & $2.54 \%$ \\
capital-to-labor ratio & 0.6950 & 0.6943 & 0.6927 \\
\hline \hline
\end{tabular}

${ }^{1}$ Deviation form benchmark in percent.

The macroeconomic effects of both reforms are given in table 3. The main findings are as follows: First, implementing the first reform leads to a substantial decrease in the equilibrium unemployment rate from 7.5 to 6.4 percent. Clearly, unemployed households in the second tier, that means those who already lost their entitlement to high benefit payments, increase their search effort in order to escape the state with low benefits more quickly. Moreover, for unemployed households who are still eligible for high benefit payments, losing their entitlement

\footnotetext{
${ }^{14}$ In fact, by the introduction of Unemployment Benefit II, Unemployment Assistance and Social Assistance were merged.

${ }^{15}$ The pre-reform Unemployment Benefit was relabeled as Unemployment Benefit I, in order to make the distinction between the newly introduced Unemployment Benefit II.
} 
becomes more threatening now, wherefore they increase their search effort, as well. Decomposing the contribution of both mechanisms to the decrease in the unemployment rate reveals that 57 percent of the decrease is due to the reaction of the households who lost their entitlement to high benefit payments directly. The remaining 43 percent are explained by search effort adjustments due to the increasing threat, that means, the increasing risk. The adjustments of the individual search effort decisions to the labor market reforms are given in table 4.

When the eligibility period is reduced according to the second reform, those households who still enjoy the high benefit rate will intensify their job search to avoid losing their entitlements to high benefit payments. However, in order of magnitude, this effect is not very important, and the unemployment rate decreases by 0.13 percentage points with respect to the first reform. Put differently, the search effort decision and thus the re-employment probability is quite insensitive to the duration of high benefit entitlements. This finding is consistent with recent empirical research, e.g. by Caliendo, Tatsiramos and Uhlendorff (2009) and Fitzenberger and Wilke (2010). In particular, Caliendo, Tatsiramos and Uhlendorff (2009) find that the re-employment probability peaks only for those households who are close to the exhaustion period of high benefit entitlements. Thus, if we reduce the eligibility period, only the households who become close to the new exhaustion period will raise their search effort, whereas the other households' search effort decision is almost unaffected. Our model, however, abstracts from the exhaustion period effect, since every unemployed household with high entitlements faces the same expected period of remaining entitled to high benefits, $\frac{1}{\sigma_{b}}$ quarters. Thus, no unemployed agent is close to the exhaustion period, making the adjustment of search effort negligible, and the equilibrium unemployment rate is hardly affected by the implementation of the second reform. Since we abstract from the exhaustion period effect, our results for the second reform have to be interpreted more cautiously as a lower bound.

Second, the average consumption growth rate increases by 0.06 and 0.08 percentage points on an annual basis for reform 1 and reform 2, respectively. For the average consumption growth rate, there are two detrimental forces at work. On the one hand, human capital risk increases and discourages households to accumulate human capital, which leads to a downward pressure on the aggregate consumption growth rate. On the other hand, there are more employed households in the new equilibrium who accumulate human capital at higher rates than unemployed households. 
Table 4: Household Policies

\begin{tabular}{lccc}
\hline \hline & BENCHMARK & REFORM 1 & REFORM 2 \\
\hline$\theta$ & 0.3916 & 0.3941 & 0.3943 \\
$\pi^{n}\left(l\left(u^{g h}\right)\right)$ & 0.5172 & 0.5379 & 0.5427 \\
$\pi^{n}\left(l\left(u^{g l}\right)\right)$ & 0.5172 & 0.5672 & 0.5670 \\
$\pi^{s}\left(l\left(u^{6 h}\right)\right)$ & 0.1667 & 0.2137 & 0.2233 \\
$\pi^{s}\left(l\left(u^{6 \ell}\right)\right)$ & 0.1667 & 0.2618 & 0.2616 \\
\hline \hline
\end{tabular}

This leads to an upward pressure on the aggregate consumption growth rate. In our numerical example, the second effect dominates the first one. In a similar vein, we find that the equilibrium capital-to-labor ratio is almost unaffected by the labor market reforms since there are two detrimental forces at work. Discouraging human capital investment obviously raises $\frac{K_{t}}{H_{t}^{e}}$ while the employment effect tends to raise the absolute amount of human capital used in production such that $\frac{K_{t}}{H_{t}^{e}}$ decreases. Numerically, both effects almost offset each other.

Third, the increase in average consumption growth is accompanied by a considerable level effect on equilibrium consumption. In particular, the decreasing unemployment rate leads to an increase in production which finally allows an upward shift of the consumption path by 0.96 and 1.12 percent for reform 1 and 2, respectively. From a different point of view, we see that the reduction of the marginal benefit rate in the second tier, reform 1 , the reduction of the eligibility period to high benefit payments in the first tier, reform 2 , and the decrease in the total unemployment rate substantially reduce the total amount of benefit payments. Hence, the government needs less tax revenue in order to meet its balanced budget constraint, wherefore it reduces the consumption tax rate from 3.66 to 2.69 and 2.54 percent for labor market reforms 1 and 2, respectively. Clearly, reducing the cost of consumption heaves the consumption path to a higher level.

Considering social welfare, which we define as the equally weighted average of the households' life time utility, there are again two detrimental forces at work when we implement the labor market reforms. On the one hand, households enjoy a tax cut which allows them to consume more in each period and, thus, raises their lifetime utility. On the other hand, reducing benefit payments and shortening the entitlement period to high benefit payments increase the individual 
Table 5: Welfare Effect of Labor Market Reforms

\begin{tabular}{lcccccc}
\hline \hline & \multicolumn{3}{c}{ REFORM 1} & \multicolumn{3}{c}{ REFORM 2} \\
& WELFARE & LEVEL & INSURANCE & WELFARE & LEVEL & INSURANCE \\
\hline$\Delta$ & $0.41 \%$ & $1.93 \%$ & $-1.52 \%$ & $0.45 \%$ & $2.02 \%$ & $-1.57 \%$ \\
$\Delta \mid s_{1 t}=e$ & $0.48 \%$ & $1.93 \%$ & $-1.45 \%$ & $0.52 \%$ & $2.02 \%$ & $-1.50 \%$ \\
$\Delta \mid s_{1 t}=u^{g h}$ & $0.17 \%$ & $1.93 \%$ & $-1.76 \%$ & $0.18 \%$ & $2.02 \%$ & $-1.84 \%$ \\
$\Delta \mid s_{1 t}=u^{g l}$ & $-0.32 \%$ & $1.93 \%$ & $-2.15 \%$ & $-0.27 \%$ & $2.02 \%$ & $-2.29 \%$ \\
$\Delta \mid s_{1 t}=u^{6 h}$ & $-0.53 \%$ & $1.93 \%$ & $-2.46 \%$ & $-0.63 \%$ & $2.02 \%$ & $-2.65 \%$ \\
$\Delta \mid s_{1 t}=u^{6 l}$ & $-1.70 \%$ & $1.93 \%$ & $-3.63 \%$ & $-1.65 \%$ & $2.02 \%$ & $-3.67 \%$ \\
\hline
\end{tabular}

income risk which leads to losses of lifetime utility when households are risk averse. In order to quantify the welfare effects, we follow LuCAS (1987) and ask the households in the pre-reform state how much additional consumption do they need in each period in order to be indifferent between implementing the reform or not. Specifically, let $\Delta$ denote the respective percentage share satisfying

$$
\mathbb{E}_{S}\left[\sum_{t=0}^{\infty} \beta^{t} \log \left((1+\Delta) c_{t}\right)\right]=\mathbb{E}_{S}\left[\sum_{t=0}^{\infty} \beta^{t} \log c_{t}^{r e f}\right]
$$

where $\left\{c_{t}\right\}_{t=0}^{\infty}$ denotes the households' consumption plans without labor market reforms and $\left\{c_{t}^{r e f}\right\}_{t=0}^{\infty}$ is the consumption plan when the reform is implemented in period 0 . In table 5, we we report the welfare effects ${ }^{16}$ and find substantial welfare gains of 0.41 and 0.45 for reform 1 and reform 2, respectively. Hence, the welfare improving level effect of consumption dominates the welfare reducing effect from losing insurance. Clearly, the currently employed households benefit most from the labor market reforms since the loss of insurance imposes only second order risk to them in the sense that they first have to become unemployed before being directly exposed to the risk of losing the high entitlements. More surprisingly, those unemployed agents who receive the high benefit payments and are good job seekers realize a slightly positive welfare gain from the labor market reforms. Hence, for them it still holds that the level effect of a

\footnotetext{
${ }^{16}$ For the computation of the welfare effects, we take the transition phase into account. Details on the computation are deferred to the appendix.
} 
higher consumption path dominates the loss of insurance. For the other types of unemployed agents, however, the loss of insurance dominates, leading to substantial welfare losses. Table 5 also reports the decomposition of the welfare effect into level and insurance effect. Further reductions in the benefit rate, however lead only to negligible additional welfare gains, if at all.

Table 6: Macroeconomic Effects of the Labor Market Reform 1 - Different Target Elasticities

\begin{tabular}{lcccc}
\hline \hline & BENCHMARK & $\eta_{\pi, b}=-1.14$ & $\eta_{\pi, b}=-1$ & $\eta_{\pi, b}=-0.5$ \\
\hline unemployment rate & $7.50 \%$ & $6.38 \%$ & $6.46 \%$ & $6.82 \%$ \\
share of long-term unemployment & $42.0 \%$ & $32.8 \%$ & $33.5 \%$ & $36.6 \%$ \\
annualized growth rate & $2.00 \%$ & $2.06 \%$ & $2.05 \%$ & $2.03 \%$ \\
level effect on consumption ${ }^{1}$ & $0.00 \%$ & $0.96 \%$ & $0.93 \%$ & $0.83 \%$ \\
consumption tax rate & $3.66 \%$ & $2.69 \%$ & $2.72 \%$ & $2.81 \%$ \\
capital-to-labor ratio & 0.6950 & 0.6943 & 0.6944 & 0.6946 \\
\hline \hline
\end{tabular}

${ }^{1}$ Deviation form benchmark in percent.

Clearly, the reaction of the equilibrium unemployment rate to the labor market reforms depends crucially on the elasticity of the the job finding probability with respect to the benefit rate. The more elastic the job finding probability, the stronger the decrease in the unemployment rate which finally leads to a stronger increase in aggregate production and social welfare. Put differently, the more elastic the job finding probability, the stronger the level effect of consumption to social welfare. To assess the importance of this elasticity with respect to our results, we recalibrate the model to a target elasticity of $\eta_{\pi, b}=-1.0$ and $\eta_{\pi, b}=-0.5$ which is already in the range of values estimated for the United Kingdom and thus, a lower bound (in absolute terms) for our analysis. Since the second reform has only negligible effects, we focus on the first reform only. The macroeconomic effects of the re-calibrated model are given in table 6. As expected, the more inelastic the job finding probability with respect to benefit payments, the higher the unemployment rate: setting the elasticity to -1.0 yields an equilibrium unemployment rate of 6.5 percent and for an elasticity of -0.5 , the unemployment only decreases to 6.8 percent. The smaller employment effect on aggregate output finally translates into lower welfare effects that are given in table 7 . 
Table 7: Welfare Effect of Labor Market Reform 1 - Different Target Elasticities

\begin{tabular}{lccc}
\hline \hline & $\eta_{\pi, b}=-1.14$ & $\eta_{\pi, b}=-1.0$ & $\eta_{\pi, b}=-0.5$ \\
\hline$\Delta$ & $0.41 \%$ & $0.38 \%$ & $0.23 \%$ \\
$\Delta \mid s_{1 t}=e$ & $0.48 \%$ & $0.45 \%$ & $0.31 \%$ \\
$\Delta \mid s_{1 t}=u^{g h}$ & $0.17 \%$ & $0.14 \%$ & $-0.03 \%$ \\
$\Delta \mid s_{1 t}=u^{g l}$ & $-0.32 \%$ & $-0.36 \%$ & $-0.55 \%$ \\
$\Delta \mid s_{1 t}=u^{6 h}$ & $-0.53 \%$ & $-0.59 \%$ & $-0.84 \%$ \\
$\Delta \mid s_{1 t}=u^{6 l}$ & $-1.70 \%$ & $-1.77 \%$ & $-2.10 \%$ \\
\hline \hline
\end{tabular}

\section{Conclusions}

We develop a dynamic stochastic general equilibrium model with labor market search and incomplete markets which remains despite ex-post heterogenous agents tractable in the sense that the equilibrium can be characterized without knowing the underlying wealth distribution. The model allows the analysis of the unemployment insurance's major tradeoff between insuring households against earning and consumption volatility and providing an incentive to exert search effort. In contrast to the existing literature, our model also considers long-run growth effect of the unemployment insurance system.

Applying the model to evaluate the welfare and growth effects of the recent labor market reforms in Germany, we find that society as whole benefits from these reforms and, furthermore, even short-term unemployed benefit since the loss of insurance is dominated by the employment effect. The results remain quite robust throughout variations of the critical calibration target, the elasticity of the job finding rate with respect to the benefit level. Although this reform yields substantial welfare gains, decreasing the benefit rate in the second tier further only causes negligible additional welfare gains since the social welfare function is already quite flat in $b^{h}-b^{\ell}$ space.

Further research is devoted to the analytical derivation of optimal unemployment schedules with explicit focus on the equilibrium growth effects of those reforms. The analysis of optimal unemployment insurance is feasible due to the straightforward simple characterization of the stationary equilibrium in our model. 


\section{References}

Acemouglu, Daron/Shimer, Robert 1999: Efficient Unemployment Insurance, in: Journal of Political Economy, Vol. 107(5), pp. 893-928.

Acemouglu, Daron/Shimer, Robert 2000: Productivity Gains from Unemployment Insurance, in: European Economic Review, Vol. 44, pp. 1145-1224.

AiYagari, RAO S. 1994: Uninsured Idiosyncratic Risk and Aggregate Saving, in: Quarterly Journal of Economics, Vol. 109(3), pp. 659-684.

Andolfatto, David 1996: Business Cycles and Labor-Market Search, in: American Economic Review, Vol. 86(1), pp. 112-132.

Addison, John T./Centeno, Màrio/Portugal, Pedro 2008: Unemployment Benefits and Reservation Wages: Key Elasticities from a Stripped-Down Job-Search Approach, IZA Discussion Paper No. 3357, Bonn.

Bachmann, Ronald 2005: Labour Market Dynamics in Germany: Hirings, Separations, and Job-to-Job Transitions over the Business Cycle, SFB 649 Discussion Paper No. 2005 - 045, Berlin.

Burda, Michael C./Mertens, Antje 1998: Wages and Worker Displacement in Germany, CEPR Discussion Paper No. 1869, London.

Benhabib, Jess/Bull, Clive 1983: Job Search: The Choice of Intensity, in: Journal of Political Economy, Vol. 91(5), pp. 747-764.

Böhringer, Christoph/Boeters, Stefan/Feil, Michael 2005: Taxation and Unemployment: an Applied General Equilibrium Approach, in: Economic Modelling, Vol. 22(1), pp. 81-108.

Browning, Martin/Hansen, Lars. P./Heckman, James. J. 1999: Micro Data and General Equilibrium Models, in: Taylor, John B./Woodford, Michael (eds.): Handbook of Macroeconomics. Handbooks in Economics, Vol. 15, pp. 543-633, Amsterdam, New York and Oxford. 
Caliendo, Marcus/Tatsiramos, Konstantinos/Uhlendorff, Arne 2009: Benefit Duration, Unemployment Duration and Job Match Quality: A Regression-Disontinuity Approach, in: IZA Discussion Paper No. 4670, Bonn.

Costain, James S./Reiter, Michael 2005: Stabilization Versus Insurance: Welfare Effects of Procyclical Taxation Under Incomplete Markets, mimeo.

Farber, Henry G. 2003: Job Loss in the United States: 1981 - 2001, NBER Working Paper No. 9707, Cambridge (MA).

Fitzenberger, Bernd/Wilke, Ralf A. 2010: New Insights into Unemployment Duration and Post-Unemployment Earnings in Germany, in: Oxford Bulletin of Economics and Statistics (forthcoming).

Franz, WolfGang 2009: Arbeitsmarktökonomik, 7th edition, Heidelberg.

Franz, Wolfgang/Gürtzgen, Nicole/Schubert, Stefanie/Clauss, Markus 2007:

Reformen im Niedriglohnsektor - eine Integrierte CGE-Mikrosimulationsstudie der Arbeitsangebots- und Beschäftigungseffekte, in: ZEW Discussion Paper No. 07-085, Mannheim.

İmrohoroĞLu, Ayşe 1992: Cost of Business Cycles with Indivisibilities and Liquidity Constraints, in: Journal of Political Economy, Vol. 97(6), pp. 1364-1383.

Hopenhayn, Hugo A./Nicolini, Juan P. 1997: Optimal Unemployment Insurance, in: Journal of Political Economy, Vol. 105(2), pp. 412-438.

Hubbard, R. Glenn/Skinner, Jonathan/Zeldes, Stephen P. 1995: Precautionary Saving and Social Insurance, in: Journal of Political Economy, Vol. 103(2), pp. 360-399.

Huggett, Mark 1993: The Risk-Free Rate in Heterogeneous-Agent Incomplete-Insurance Economies, in: Journal of Economic Dynamics and Control, Vol. 17(5-6), pp. 953-969.

Immervoll, Herwig/Kleven, Henrik J./Kreiner, Claus T./Saez, Emmanuel 2007: Welfare Reform in European Countries: a Microsimulation Analysis, in: The Economic Journal, Vol. 117(1), pp. 1-44. 
Jacobson, Louis S./Lalonde, Robert J./Sullivan, Daniel G. 1993: Earning Losses of Displaced Workers, in: American Economic Review, Vol. 83(4), pp. 685-709.

Jones, Larry E./Manuelli, Rodolfo E. 1990: A Convex Model of Equilibrium Growth: Theory and Policy Implications, in: Journal of Political Economy, Vol. 98(5), pp. 10081038.

Jung, Philip/Kuhn, Moritz 2010: Labor Market Rigidity and Business Cycle Volatility, University of Mannheim, mimeo.

Kletzer, Lori G. 1998: Job Displacement, in: Journal of Economic Perspectives, Vol. 12(1), pp. $115-136$.

Krebs, Tom 2003: Human Capital Risk and Economic Growth, in: Quarterly Journal of Economics, Vol. 118(2), pp. 709-744.

KreBs, Tom 2006: Recursive Equilibrium in Endogenous Growth Models with Incomplete Markets, in: Economic Theory, Vol. 29(3), pp. 505-523.

Krebs, Tom/Yao, Yao 2009: Labor Income Risk in German: An Empirical Analysis, University of Mannheim, mimeo.

Krusell, Per/Mukoyama, Toshiniko/ŞAhin, Ayşegül 2009: Labor-Market Matching with Precautionary Savings and Aggregate Fluctuations, in: NBER Working Papers 15282, Cambridge (MA).

Launov, Andrey/Wälde, Klaus 2010: Estimating Incentive and Welfare Effects of NonStationary Unemployment Benefits, in: IZA Discussion Paper No. 4958, Bonn.

Lentz, Rasmus 2009: Optimal Unemployment Insurance in an Estimated Job Search Model with Savings, in: Review of Economic Dynamics, Vol. 12(1), pp. 37-57.

Ljungqvist, Lars/Sargent, Thomas E. 1998: The European Unemployment Dilemma, in: Journal of Political Economy, Vol. 106(3), pp. 514-550.

LuCAS, RoBert E. 1987: Models of Business Cycles, Oxford. 
Lucas, Robert E. 1988: On the Mechanics of Economic Development, in: Journal of Monetary Economics, Vol. 22(1), pp. 3-42.

Lucas, Robert E./Prescott, Edward C. 1974: Equilibrium Search and Unemployment, in: Journal of Economic Theory, Vol. 7(2), pp. 188-209.

McCall, John J. 1970: Economics of Information and Job Search, in: Quarterly Journal of Economics, Vol. 84(1), pp. 113-126.

Meghir, Costas/Pistaferri, Luigi 2004: Income Variance Dynamics and Heterogeneity, in: Econometrica, Vol. 72(1), pp. 1-32.

Merz, Monika 1995: Search in the Labor Market and the Real Business Cycle, in: Journal of Monetary Economics, Vol. 36(2), pp. 269-300.

Meyer, Bruce D./Mok, Wallace K. C. (2007): Quasi-Experimental Evidence on the Effects of Unemployment Insurance from New York State, in: NBER Working Paper No. 12865.

Nakajima, Makoto 2008: Business Cycles in the Equilibrium Model of Labor Market Search and Self-Insurance, mimeo.

OECD 2006: Employment Outlook 2006, Paris.

Phelps, Edmund S. 1968: Money-Wage Dynamics and Labor-Market Equilibrium, in: Journal of Political Economy, Vol. 76, pp. 678-711.

Pissarides, Christopher A. 1979: Job Matchings with State Employment Agencies and Random Search, in: Economic Journal, Vol. 89(356), pp. 818-833.

Pissarides, Christopher A. 2000: Equilibrium Unemployment Theory, 2nd edition, Cambridge (MA).

Schmitz, Hendrik/Steiner, Viktor 2007: Benefit-Entitlement Effects and the Duration of Unemployment: An Ex-Ante Evaluation of Recent Labour Market Reforms in Germany, IZA Discussion Paper No. 2681, Bonn. 
Shavell, Steven/Weiss, Laurence 1979: The Optimal Payment of Unemployment Insurance Benefits over Time, in: Journal of Political Economy, Vol. 87(6), pp. 1347-1362.

Shimer, Robert/Werning, Iván 2007: Reservation Wages and Unemployment Insurance, in: Quarterly Journal of Economics, Vol. 122(3), pp. 1145-1185.

Shimer, Robert/ Werning, Iván 2008: Liquidity and Insurance for Unemployed Workers, in: American Economic Review, Vol. 98(5), pp. 1922-1942.

Storesletten, Kuetil/Telmer, Chris I./Yaron, Amir 2004: Cyclical Dynamics in Idiosyncratic Labor Market Risk, in: Journal of Political Economy, Vol. 112(3), pp. 695-717. 


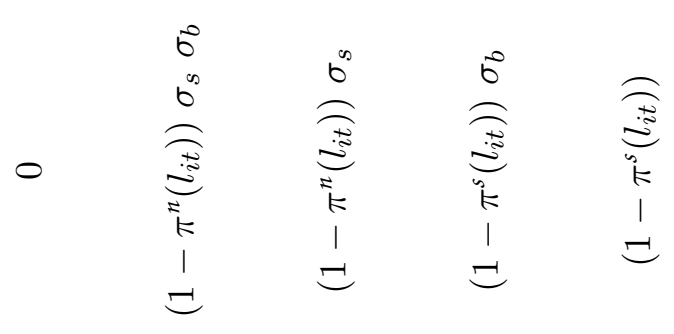
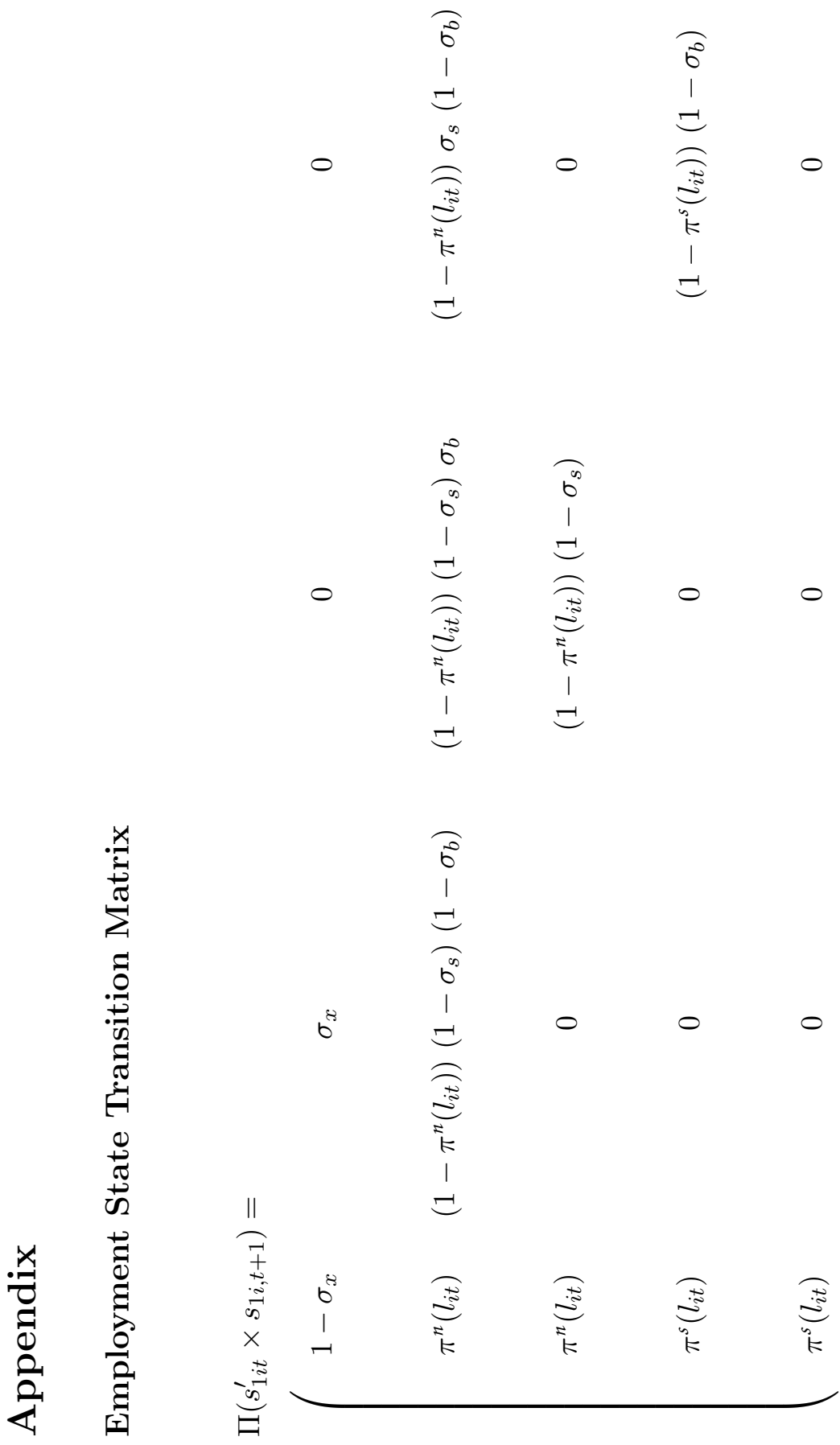


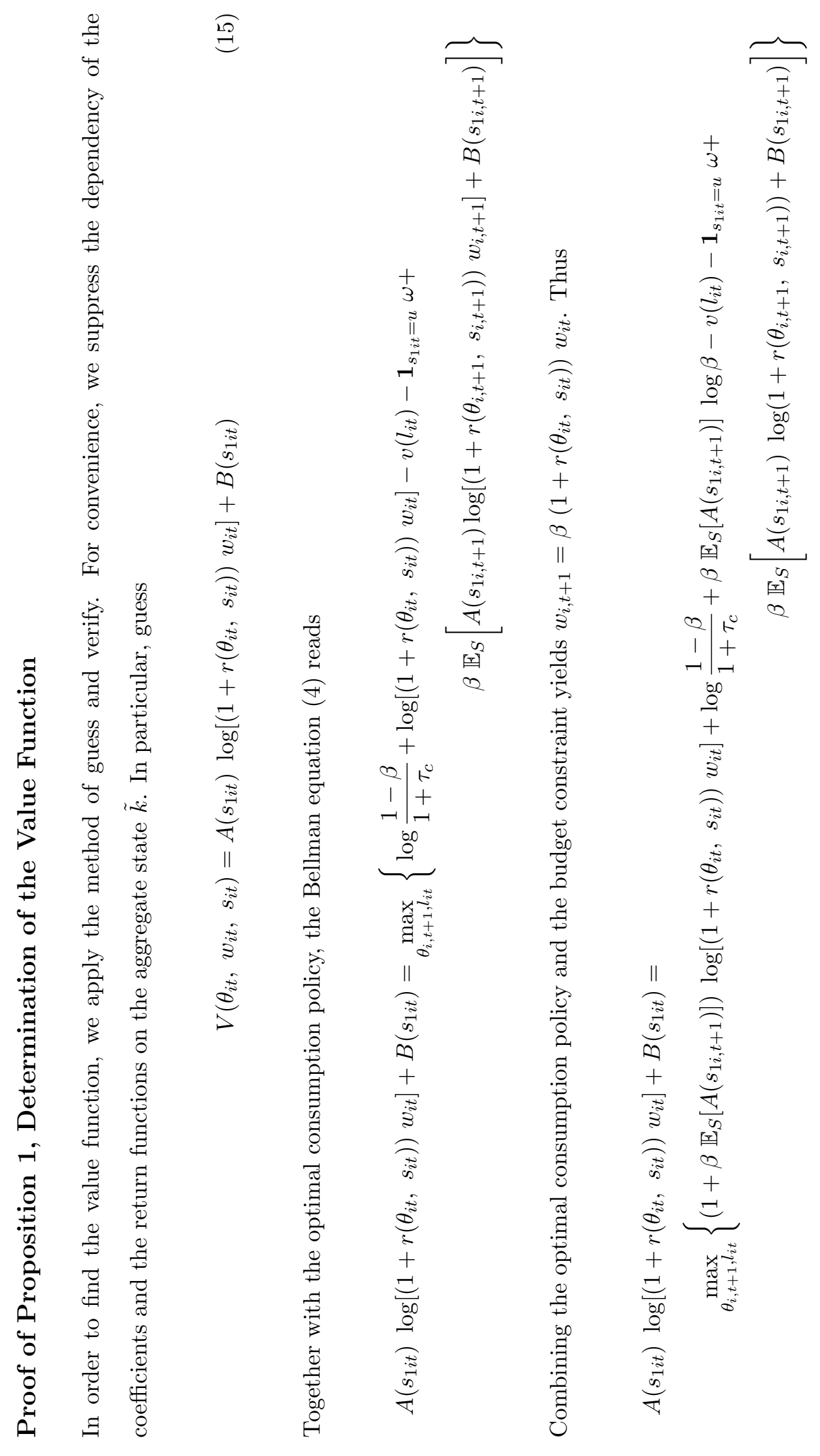




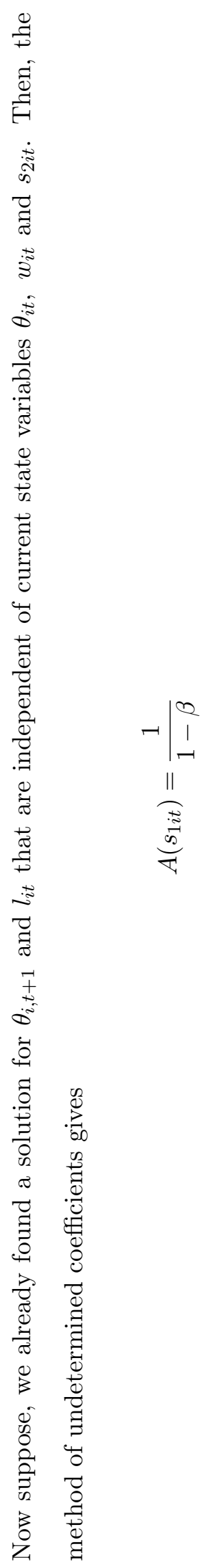

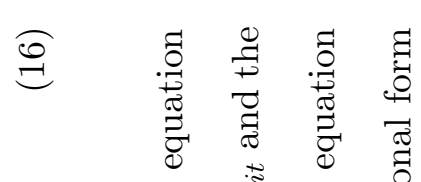

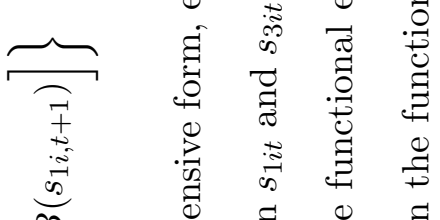

○.

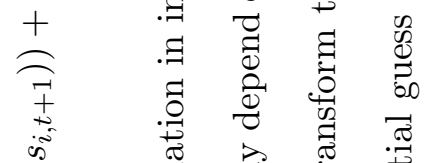

主严言焉

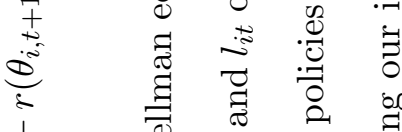

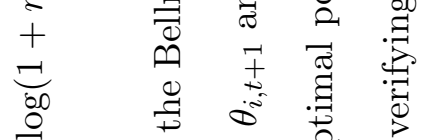

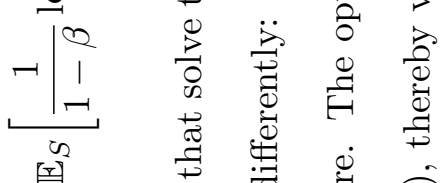

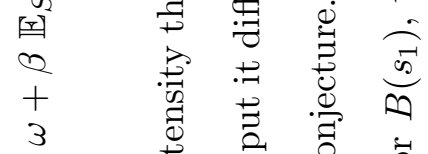

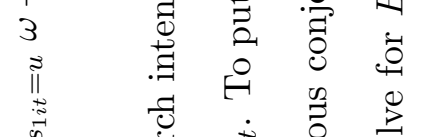

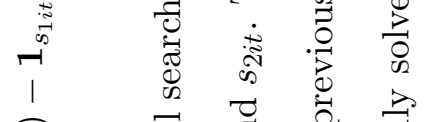

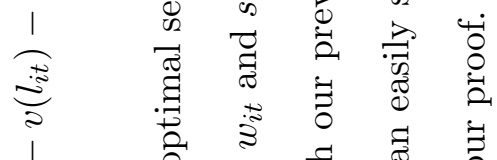

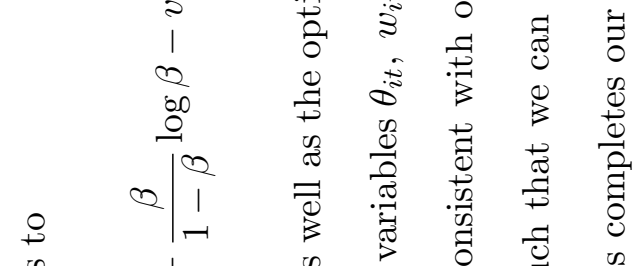

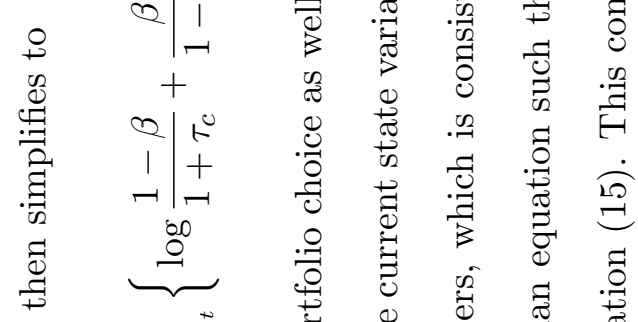

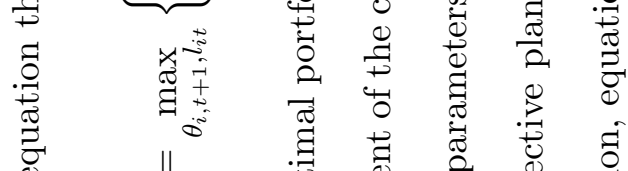

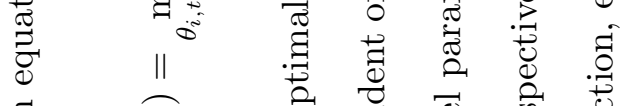

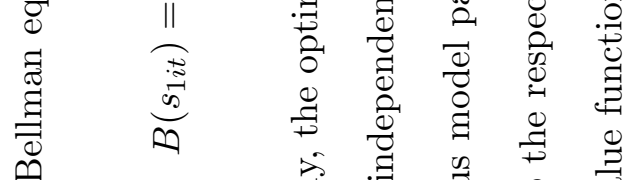

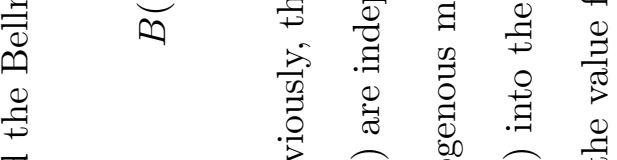

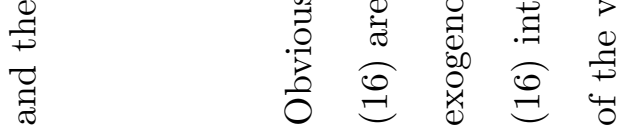




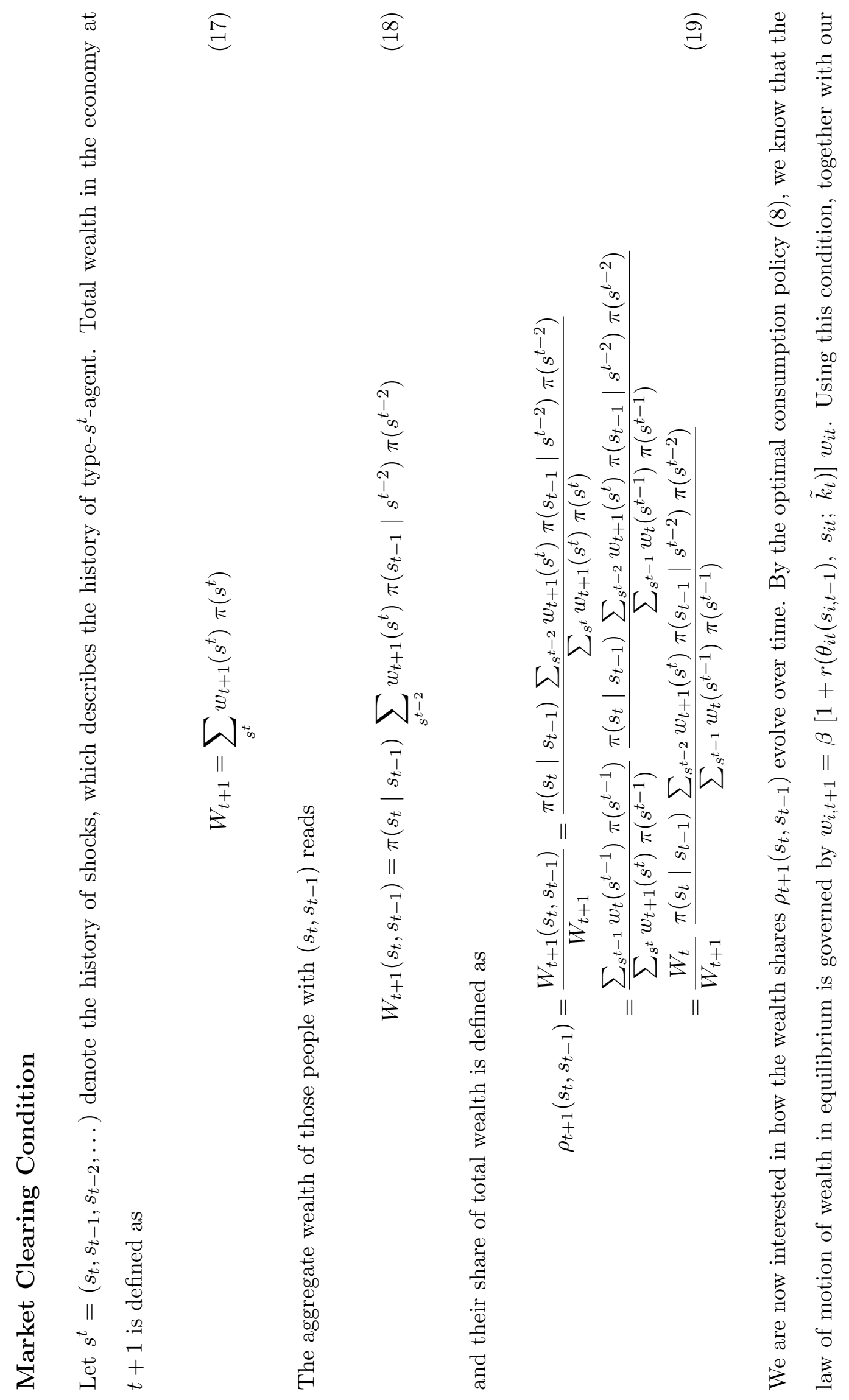




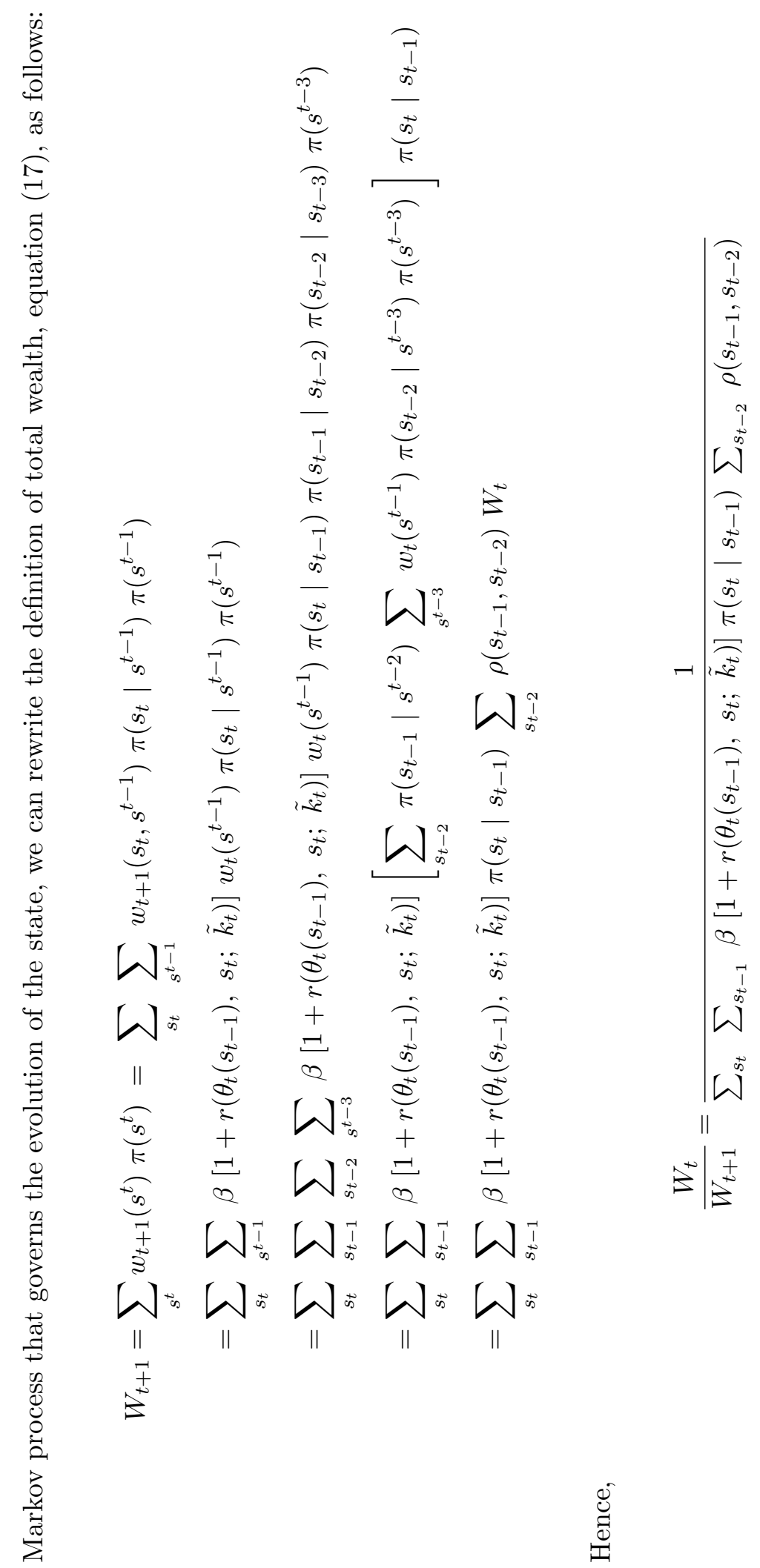


$\widehat{\overparen{\jmath}}$

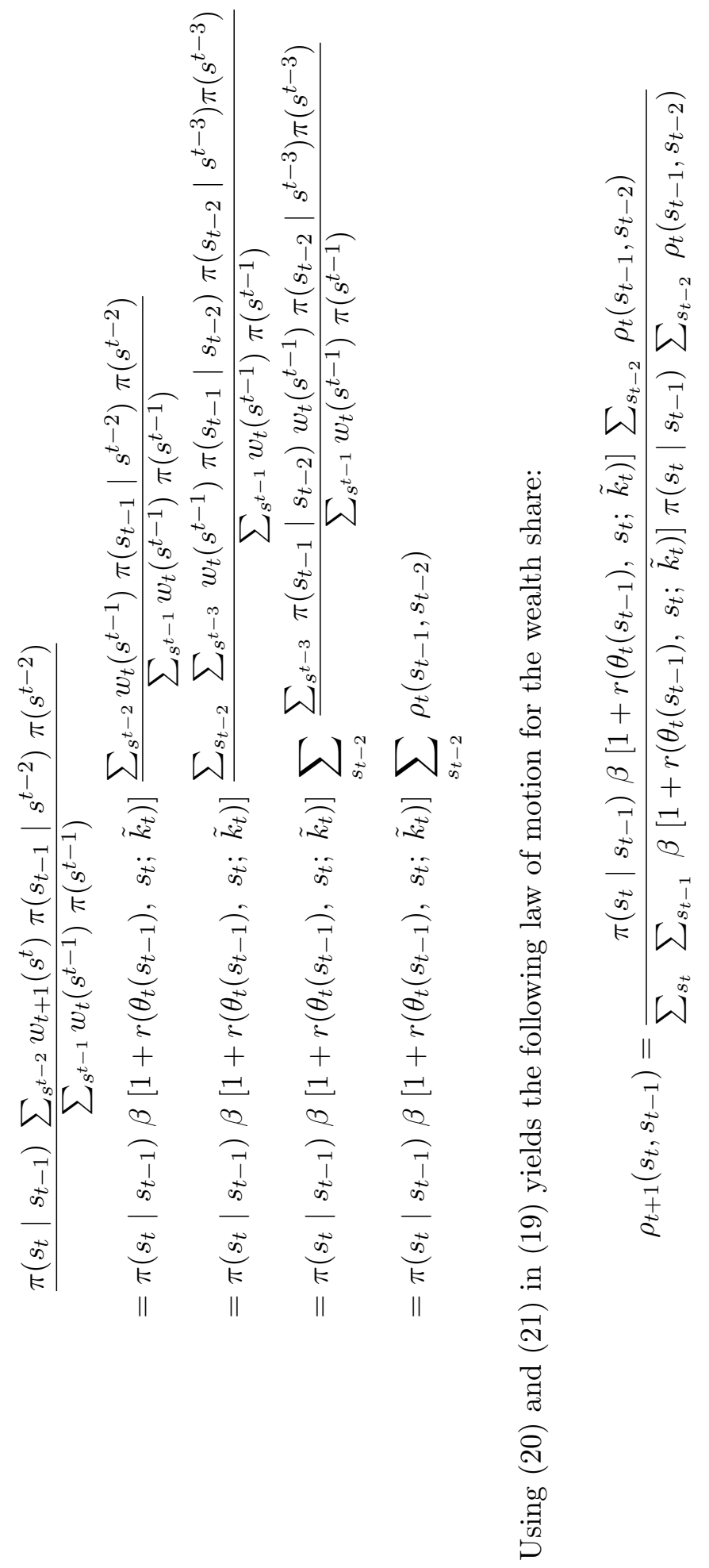




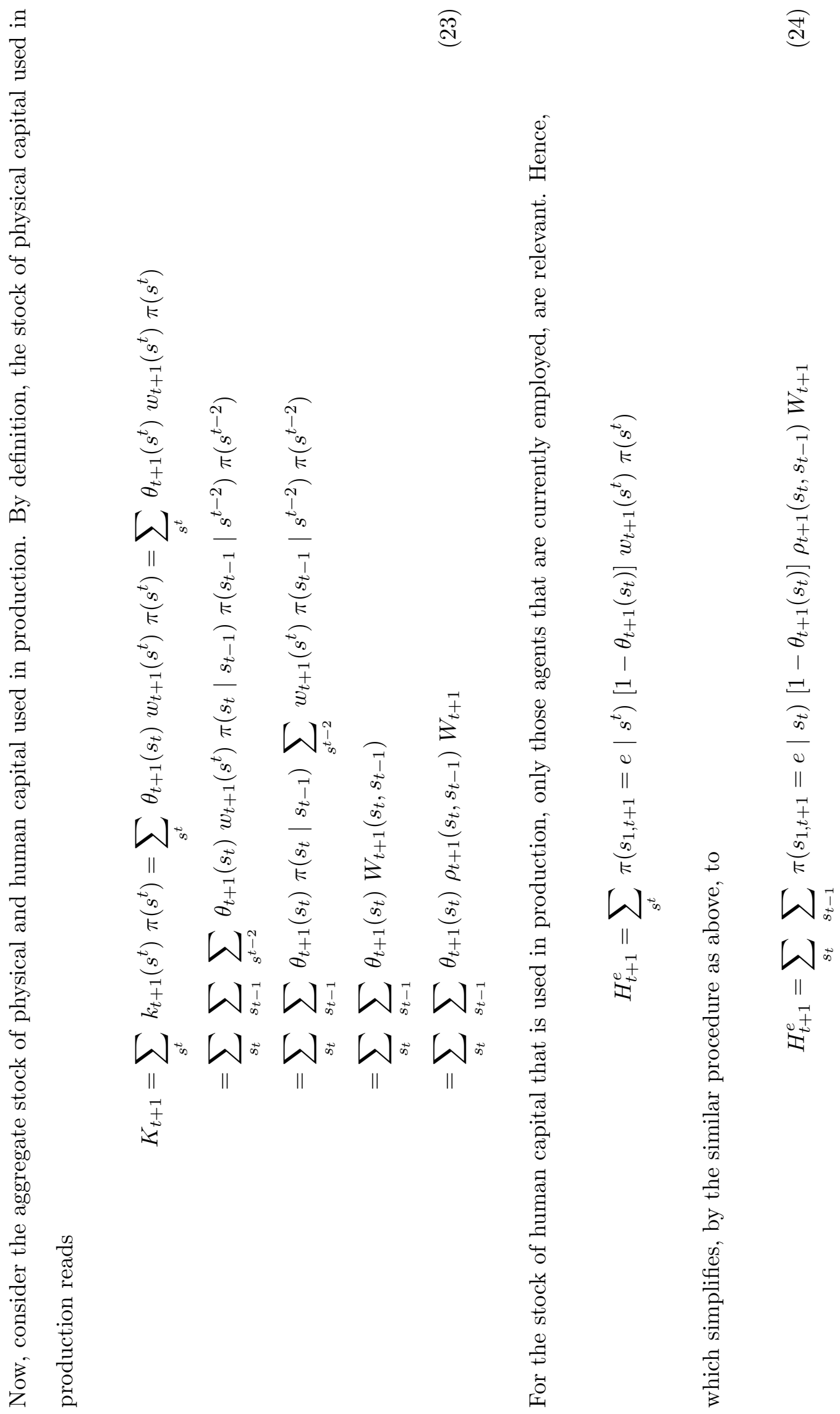




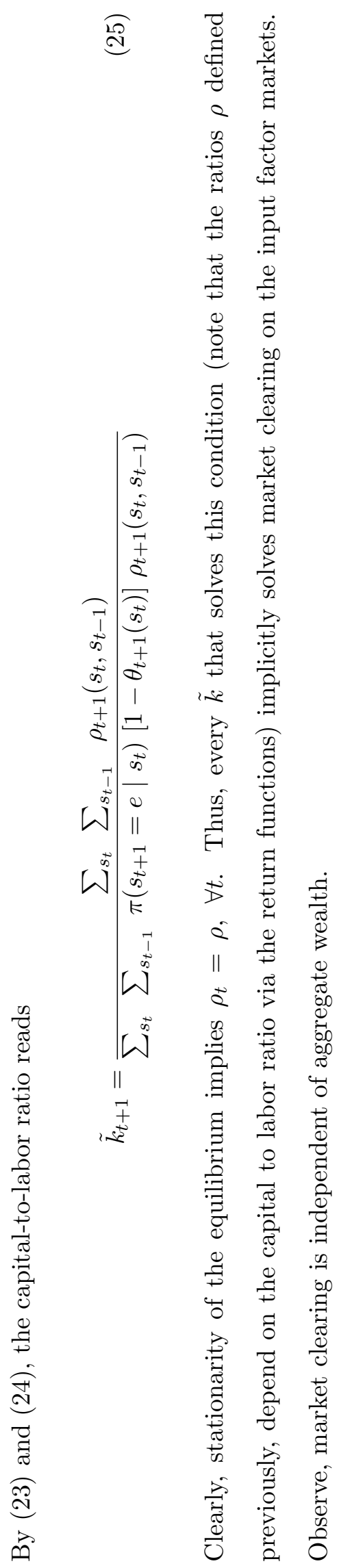



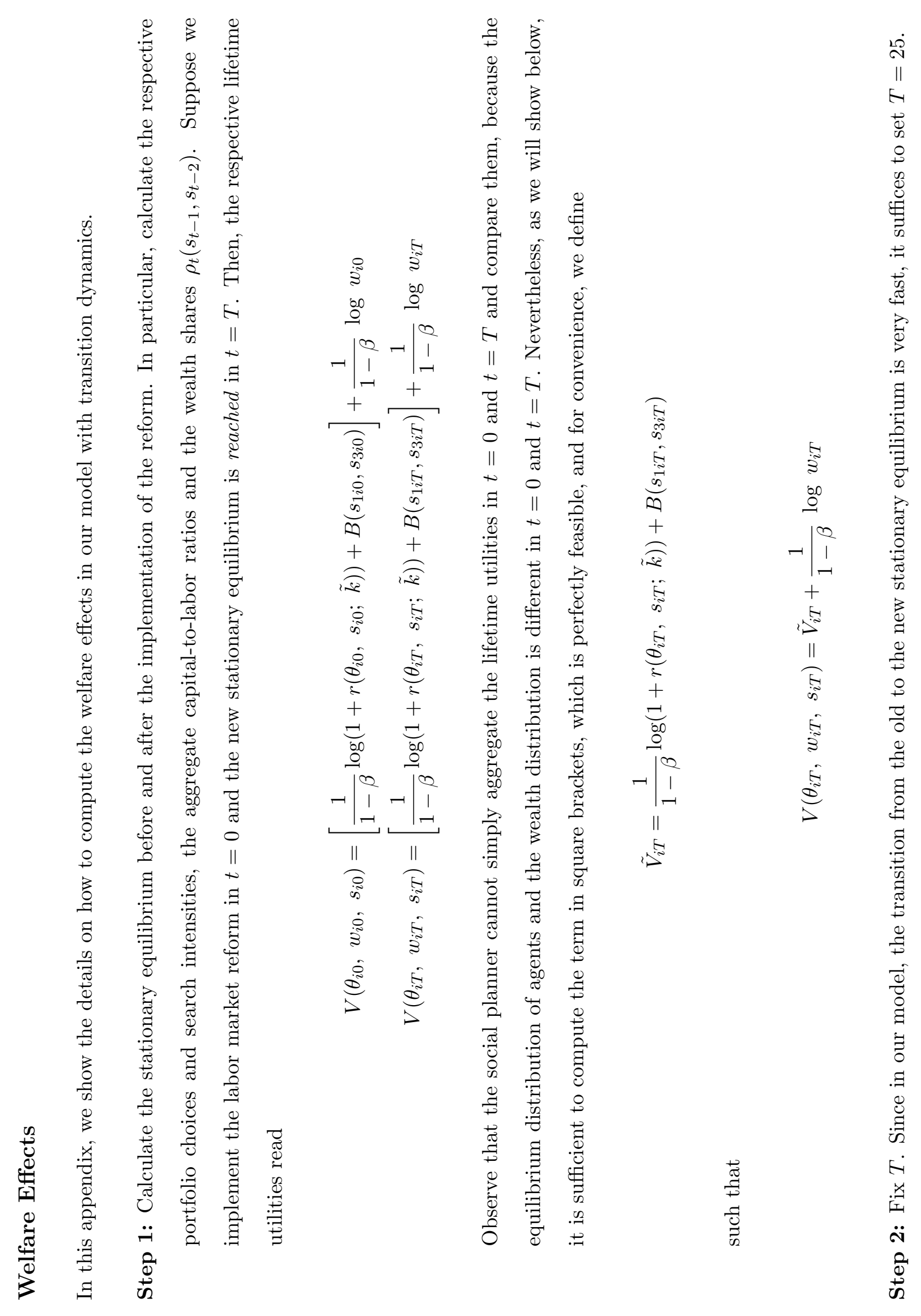


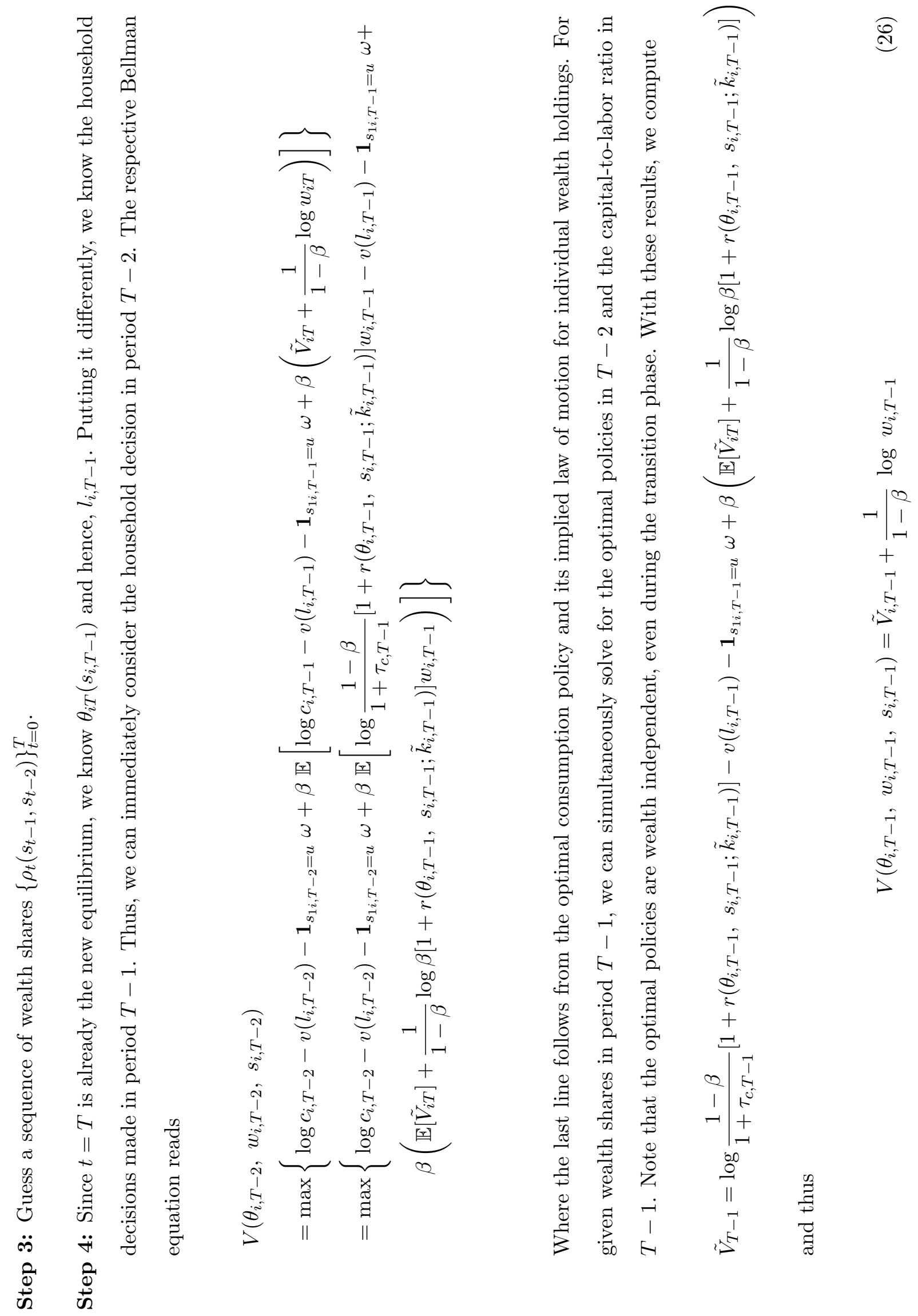




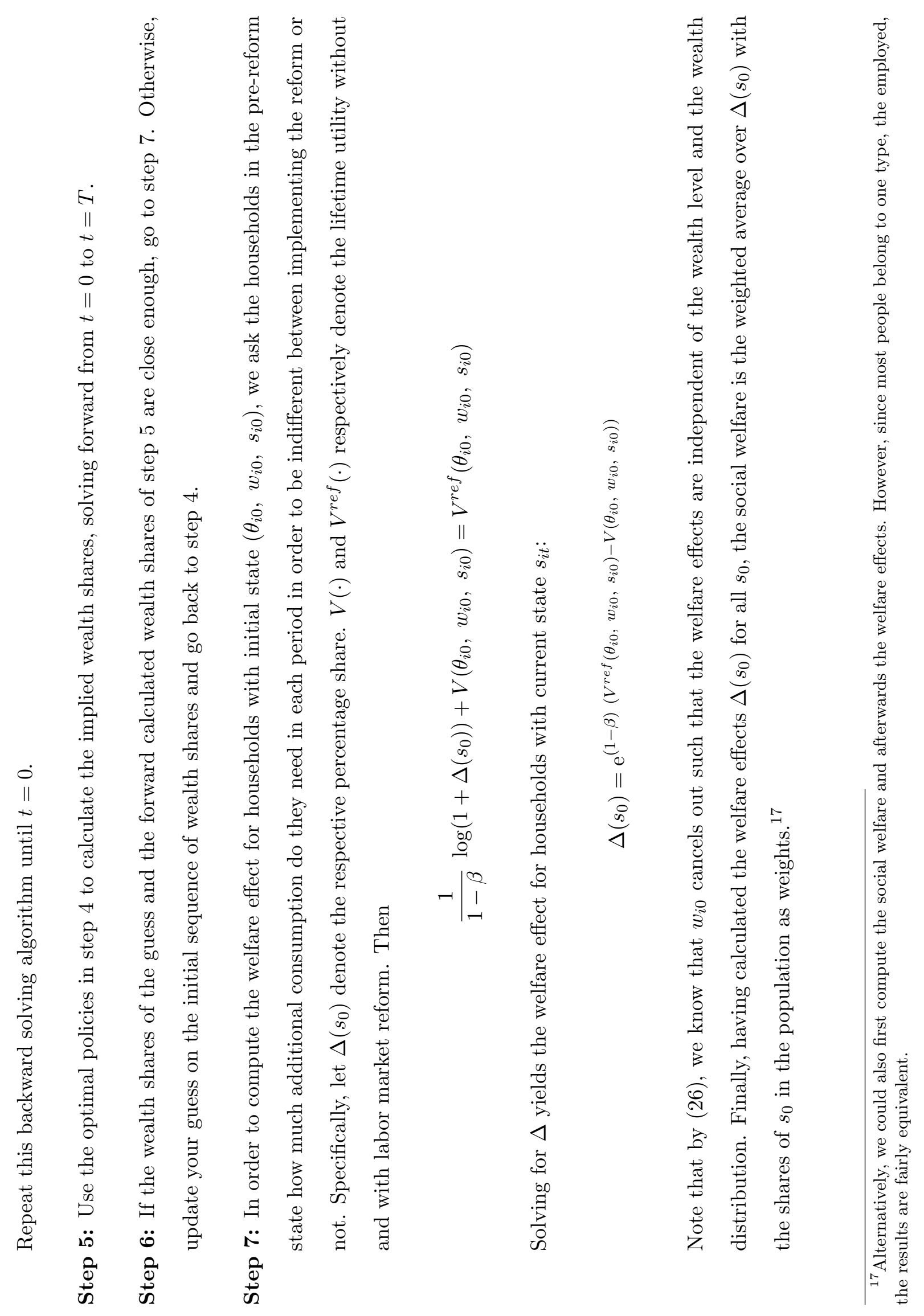

